\title{
Phylogenetic diagnosis and expanded description of the genus Mazarunia Kullander, 1990 (Teleostei: Cichlidae) from the upper Mazaruni River, Guyana, with description of two new species
}

\author{
Hernán López-Fernández ${ }^{1,2}$, Donald C. Taphorn ${ }^{3}$ and Elford A. Liverpool ${ }^{4}$
}

We expand the description of the genus Mazarunia Kullander, 1990, explore morphological diagnostic characters for the genus and for its sister-group relationship with Guianacara Kullander \& Nijssen, 1989 in a phylogenetic context, expand the description of $M$. mazarunii and describe two new species. Mazarunia can be diagnosed by the combination of numerous anatomical traits, including the unique loss of infraorbital 6, the configuration of the first epibranchial in two of the species, a well-developed posteroventral lateral expansion of the palatine that is largely contiguous with the ectopterygoid, the absence of a suture between the hyomandibular and the metapterygoid, the absence of an interarcual cartilage, fourth ceratobranchial with 2 or 3 tooth plates, a caudally scaled interoperculum, equal-sized scales in the ventral and lateral chest regions, a simple, disjunct pattern of lateral line squamation, and smooth preopercle, supracleithrum and extrascapula. Species of Mazarunia can be further distinguished from species of their sistergenus Guianacara by their distinct color patterns. Mazarunia charadrica, new species, can be distinguished from other species of Mazarunia, among other characters, by approximately equal uncinate process and anterior arm and reduced anteroventral expansion of epibranchial 1 (vS. uncinate process narrower and complete anteroventral expansion in the other two species), a dorso-ventrally flattened maxillary process of the palatine (vs. cylindrical in the other two species), cycloid (vs. ctenoid) scales in the opercular, postorbital, lateral chest and anal-genital regions, the absence of a mid-lateral spot, and a diffuse dark area covering the dorsal portion of the head giving the impression of a "black cap". Mazarunia charadrica has a unique juvenile pattern of seven vertical dark bars partially preserved in adults. Bars 3-6 in antero-caudal direction are most visible in juveniles and medium-sized specimens but become fainter and almost disappear in adults. Many specimens show only bar number 3 (midlateral bar). Mazarunia mazarunii can be distinguished from all other species of Mazarunia by the presence of two foramina (vs. one) on the lateral face of the ascending process of the premaxilla, a lachrymal bone that is longer than deep (vS. deeper than long), an infraorbital 3 that is contiguous but not overlapping with the lachrymal ( $v s$. overlapping), ctenoid scales ( $v s$. cycloid) on the subopercle, interopercle and chest, and by its unique coloration, including complete suborbital and supraorbital stripes, and being the only species of Mazarunia with a discernible lateral band formed by the mid-line blotching pattern associated with lateral bars. In large adults, M. mazarunii has a black or dark bar behind the head that produces the impression of a collar. Mazarunia pala, new species, can be distinguished from its congeners by the absence of a parhypurapophysis, the presence of a dorsal-fin scaly pad with ctenoid scales ( $v s$. no scaly pad in M. charadrica and M. mazarunii), a small suborbital stripe limited to the preopercle, the absence of clearly discernible lateral bars on the body, and by its general pinkish coloration with midlateral spot as the only melanic marking. All known species of Mazarunia are restricted to the upper reaches of the Mazaruni River basin in Guyana.

Expandimos la descripción del género Mazarunia, exploramos caracteres diagnósticos morfológicos para el género y su relación de grupo hermano con Guianacara en un contexto filogenético, expandimos la descripción de M. mazarunii y describimos dos nuevas especies. Mazarunia se puede diagnosticar por la combinación de numerosos atributos anatómicos, incluyendo la pérdida del infraorbital 6, la configuración del primer epibranquial en dos de las especies, una expansión posteroventral lateral del palatino bien desarrollada y mayormente continua con el ectopterigoide, la ausencia de sutura entre la hiomandíbula y el metapterigoide, la ausencia del cartílago interarcual, 2 a 3 placas dentadas en el cuarto ceratobranquial, la porción caudal del interopérculo escamada, escamas de igual tamaño en el flanco y la región lateral del pecho, un patrón simple y disjunto de escamación en la línea lateral, y preopérculo, supracleitro y extra escápula lisos. Además, todas las especies de Mazarunia se

\footnotetext{
${ }^{1}$ Department of Natural History, Royal Ontario Museum, 100 Queen’s Park, Toronto, Ontario, Canada M5S 2C6. hernanl@rom.on.ca ${ }^{2}$ Department of Ecology and Evolutionary Biology, University of Toronto, 25 Willcocks Street, Toronto, Ontario, Canada M5S 3B2.

${ }^{3} 1822$ N. Charles St., Belleville, IL, 62221, USA. taphorn@gmail.com

${ }^{4}$ Guyana National Museum, Ministry of Culture, Youth and Sport, Company Path, Georgetown, Guyana. elfordliverpool@yahoo.com
} 
pueden distinguir de especies en su género hermano Guianacara por diferencias de coloración. Mazarunia charadrica, especie nueva, puede distinguirse de otras especies de Mazarunia, entre otros caracteres, por tener un proceso uncinado aproximadamente igual al brazo posterior y expansión anteroventral reducida en el epibranquial 1 (contra proceso uncinado más angosto y expansión anteroventral completa en las otras dos especies), el proceso maxilar del palatino aplanado dorsoventralmente (contra cilíndrico en las otras dos especies), escamas cicloides (contra ctenoides) en las regiones opercular, postorbital, pectoral lateral y génito-anal, la ausencia de mancha mediolateral, y un área oscura difusa cubriendo la porción dorsal de la cabeza dando la impresión de un "sombrero negro". Mazarunia charadrica tiene un patrón único de coloración juvenil con siete barras verticales conservadas parcialmente en los adultos. Las barras 3-6 en dirección anterocaudal son más visibles en juveniles y especímenes de tamaño mediano pero se decoloran hasta casi desaparecer en adultos. Muchos especímenes muestran solamente la barra número 3 (barra mediolateral). Mazarunia mazarunii puede ser distinguida de todas las otras especies de Mazarunia por la presencia de dos forámenes (contra uno) en la cara lateral del proceso ascendente de la premaxila, un lacrimal más largo que ancho (contra más ancho que largo), infraorbital 3 continuo pero no sobrepuesto con el lacrimal (contra sobrepuesto), escamas ctenoides (contra cicloides) en el subopérculo, interopérculo y pecho, por su particular coloración que incluye barras sub y supraorbitales completas y por ser la única especie de Mazarunia con una banda lateral discernible formada por manchas asociadas con las barras laterales a lo largo de la línea media. En adultos grandes M. mazarunii tienen una barra negra u oscura detrás de la cabeza que produce la impresión de un collar. Mazarunia pala, especie nueva, puede distinguirse de sus congéneres por la ausencia de parahipurapófisis, la presencia de un parche de escamas ctenoides en la base de la aleta dorsal (contra ausencia del parche en $M$. charadrica y M. mazarunii), una pequeña barra suborbital limitada al preopérculo, la ausencia de barras laterales distinguibles en el cuerpo, y por su coloración general rosácea con una mancha mediolateral como única marca melánica. Todas las especies conocidas de Mazarunia están restringidas a la porción superior de la cuenca del Río Mazaruni en Guyana.

Key words: Endemism, Geophagini, Guiana shield, Guianacara.

\section{Introduction}

The genus Mazarunia Kullander has been known until recently only from the two specimens available for the original description of Mazarunia mazarunii Kullander, 1990, an endemic genus and species of the upper Mazaruni River basin in the Guyanese portion of the Guiana Shield. In 2008, a joint expedition by the Royal Ontario Museum and the University of Guyana collected specimens of both M. mazarunii and of two other cichlid species that were clearly undescribed but whose generic assignment was not immediately obvious. Molecular phylogenetic analysis (López-Fernández et al., 2010) resulted in a strongly monophyletic grouping of all three species, and this clade in turn was well supported as sister to the lowland genus Guianacara. Because the material available for description of M. mazarunii was limited to two specimens, Kullander (1990) was understandably cautious, and preferred not to damage the specimens rather than perform an extensive anatomical investigation of the new genus. Thus the original description of $M$. mazarunii relied heavily on external anatomical characters and on what was possible to glean from radiographs, but no detailed osteological analysis could be performed. Taking advantage of the newly collected material, we further test the monophyly of Mazarunia and its relationship to Guianacara by incorporating morphological characters to the molecular dataset of López-Fernández et al. (2010). We describe morphological synapomorphies of the genus, provide a complement to the original description of M. mazarunii, and describe the two additional species. Additionally, we summarize the increasingly large number of endemic fish taxa in the upper Mazaruni River basin and point out their potential vulnerability to ongoing environmental transformations in the region.

\section{Materials and Methods}

Measurements and counts follow Kullander (1986) and Kullander \& Nijssen (1989), and were taken using digital calipers recorded to the nearest $0.1 \mathrm{~mm}$. Counts of fin rays, scales, and gill rakers were made under a dissecting microscope. Scale row nomenclature follows Kullander (1996), osteological and squamation nomenclature follows LópezFernández et al. (2005) and references to higher-level classification are based on López-Fernández et al. (2010). Counts are given as the observed count followed by the number of individuals with that value in parenthesis; counts in the holotype, when appropriate, are marked with an asterisk. Where phylogenetic characters are described in the text, the numbers in parenthesis (e.g. 101-2) indicate character number (101) and its corresponding character state (2) in the matrix of López-Fernández et al. (2005). Phylogenetic characters coded for this paper are provided in Appendix 1 and the reader is directed there for further details of character states in all taxa included in the phylogenetic analysis. Type material includes all the specimens measured and some unmeasured, and encompasses all described morphological and ontogenetic variation. Vertebral counts were made from digital X-ray images and from cleared and counter-stained specimens prepared following the protocol of Taylor \& van Dyke (1985). All X-ray counts include the last half-centrum. Holotypes are deposited in the fish collection of the Center for the Study of Biodiversity, University of Guyana, Georgetown, Guyana. Institutional abbreviations are: ANSP, Academy of Natural Sciences of Philadelphia, Philadelphia, USA; UG/CSBD, fish collection of the Center for the Study of Biodiversity, University of Guyana, Georgetown, Guyana; ROM, Royal Ontario Museum, Toronto, Canada. 
To further test the monophyly and sister relationship of Mazarunia, and to determine morphological synapomorphies for the genus, we performed a phylogenetic analysis of all Geophagini taxa using a combination of morphological and molecular data. The morphological dataset of 136 characters for 38 taxa from López-Fernández et al. (2005) was expanded to 43 taxa that include all three species of Mazarunia plus Guianacara dacrya Arbour \& López-Fernández, 2011 and G. owroewefi Kullander \& Nijssen, 1989 as a way to increase representation of the putative sister group of Mazarunia. A molecular counterpart to the morphological dataset consisted of sequences for five genes (3 mitochondrial: 16S, ND4, Cytochrome $b$, and 2 nuclear: S7 intron 1 and RAG2) from 56 taxa analyzed by López-Fernández et al. (2010). The molecular dataset included taxa from all lineages of the tribes Geophagini and Chaetobranchini in addition to three species of Cichla Bloch \& Schneider, 1801 (Cichlini), one of Retroculus Eigenmann \& Bray, 1894 (Retroculini) and one each of the genera Mesonauta Günther, 1862, Hoplarchus Kaup, 1860 (Heroini), Astronotus Swainson, 1839 (Astronotini) and Cichlasoma Swainson, 1839 (Cichlasomatini) as representatives of all other lineages of Neotropical cichlids. Detailed descriptions of morphological characters and their coding are given by LópezFernández et al. (2005) and Appendix 1; methods for sequencing and aligning the molecular dataset are detailed in LópezFernández et al. (2010). The molecular and morphological datasets were concatenated such that all partitions could be analyzed in a total evidence framework. The morphological partition was coded as missing for 13 species for which molecular but not morphological data were available. A complete list of taxa analyzed and the type of data available for each species are provided in Appendix 2; voucher information and GenBank accession numbers for all sequences are provided in López-Fernández et al. (2010). Phylogenetic analysis of the concatenated dataset was performed under maximum parsimony with all morphological characters unordered using 1000 random addition sequences and the Tree Bisection and Reconnection (TBR) algorithm in PAUP* 4.0b10 (Swofford, 2002). Results of the parsimony search were summarized using both strict and $50 \%$ majority-rule consensus. The $50 \%$ majority rule consensus tree was used to prepare a constraints file in MacClade v. 4.0 (Maddison \& Maddison, 2000) that was used in PAUP* to calculate Decay Index values (Bremer, 1994) as a measure of support for nodes using 100 replicates of TBR branch swapping with random addition sequence.

\section{Results}

\section{Phylogenetic relationships of Mazarunia}

Phylogenetic analysis resulted in eight most parsimonious trees of 11073 steps (Consistency Index $=0.3$, Retention index $=0.5$, Re-scaled consistency index $=0.15$, Fig. 1 ) that differed mostly in relationships involving species within Guianacara or basal relationships such as the position of clades outside the Geophagini (Fig. 1). Phylogenetic relationships recovered are not fundamentally different than those described by López-
Fernández et al. (2010, but see Fig. 1 and Appendix 3 of this paper). General relationships among clades within Geophagini are not discussed unless they are relevant in clarifying the relationships of Mazarunia. Results of phylogenetic analyses strongly support the monophyly of Mazarunia and its sisterrelationship to Guianacara (Fig. 1, Appendix 3), but they differ in the relationships within Mazarunia from those recovered by López-Fernández et al. (2010): while our total evidence analysis with parsimony results recovers $M$. mazarunii as sister to the other two species, the previous molecular analyses strongly recovered Mazarunia pala in that position. However, relationships recovered in our analyses are weakly supported by a Decay Index of 1 (Fig. 1). Morphological support for the monophyly of Mazarunia is provided by one unambiguous synapomorphy, two characters with uniquely derived conditions in two of the three species, and seven non-unique synapomorphies in combination (Figs. 2, 3 and see below for details).

Analysis of morphological characters from LópezFernández et al. (2005) in the context of this paper revealed new character states in three previously described characters. Expanded descriptions of these characters are as follows:

Character 116 (López-Fernández et al. 2005: Appendix 1, Fig. 2): Infraorbitals 4, 5, and 6. State [0] Autogenous, [1] 4+5 fused as a single ossicle, [2] $4+5+6$ fused as a single ossicle, [3] new character state: ossicle 6 absent (Fig. 2b-d). The monophyly of Mazarunia is supported by a unique configuration of the infraorbital series defined by the absence of the sixth infraorbital ossicle (Character 116-3, Fig. 2b-d). In Geophagini, the common configurations of infraorbital bones consist of a single fused bone formed by $4+5+6$ (Character 116-2, e.g. Satanoperca, Biotodoma, see López-Fernández et al. 2005: Fig. 2c,d) or an autogenous 6 with fused $4+5$ as that of Geophagus and Guianacara (Character 116-1, Fig. 2a). The condition in Mazarunia is unique in its absence of infraorbital 6, which has presumably been lost from the condition in its sister-genus Guianacara. We are not aware of any other Neotropical cichlids with this infraorbital configuration.

Character 100 (López-Fernández et al. 2005: Appendix 1, Fig. 7): Relative widths of the uncinate process and anterior arm of epibranchial 1. [0] Uncinate process wider, [1] both processes approximately equal, [2] new character state: uncinate process narrower than the anterior arm (Fig. 3c-d). Mazarunia mazarunii and M. pala also share the derived condition of state 2, which seems unique to the genus but is absent from M. charadrica. This condition represents a previously unrecorded character state for, at least, Geophagini (Fig. 3c,d).

Character 101 (López-Fernández et al. 2005: Appendix 1, Fig. 7): Development of an anterior laminar expansion (lobe) on epibranchial 1. [0] Absent, [1] present, fully developed, [2] present, reduced, distal to pharyngobranchial articulation, [3] present, deep instead of laminar, [4] new character state: 
reduced, proximal to the pharyngobranchial articulation (Fig. $3 \mathrm{c}-\mathrm{d})$. We interpret the laminar expansion of the first epibranchial in Mazarunia (Fig. 3c-d, Character 101-4) as different from expansions known to occur in other geophagine taxa (and see Kullander, 1998; López-Fernández et al., 2005). The Mazarunia conditions for characters 100 and 101 are clearly correlated, and superficially, are similar to the condition present in Crenicara and Dicrossus, which were originally thought to be related to Mazarunia (Kullander, 1990). However, the condition in Crenicara is clearly different in at least two respects. First, the angle between the uncinate and anterior arms in Mazarunia and its sister-group Guianacara is sharply acute, making the two arms nearly parallel (Fig. 3), while in Crenicara the angle is much wider (see Kullander,

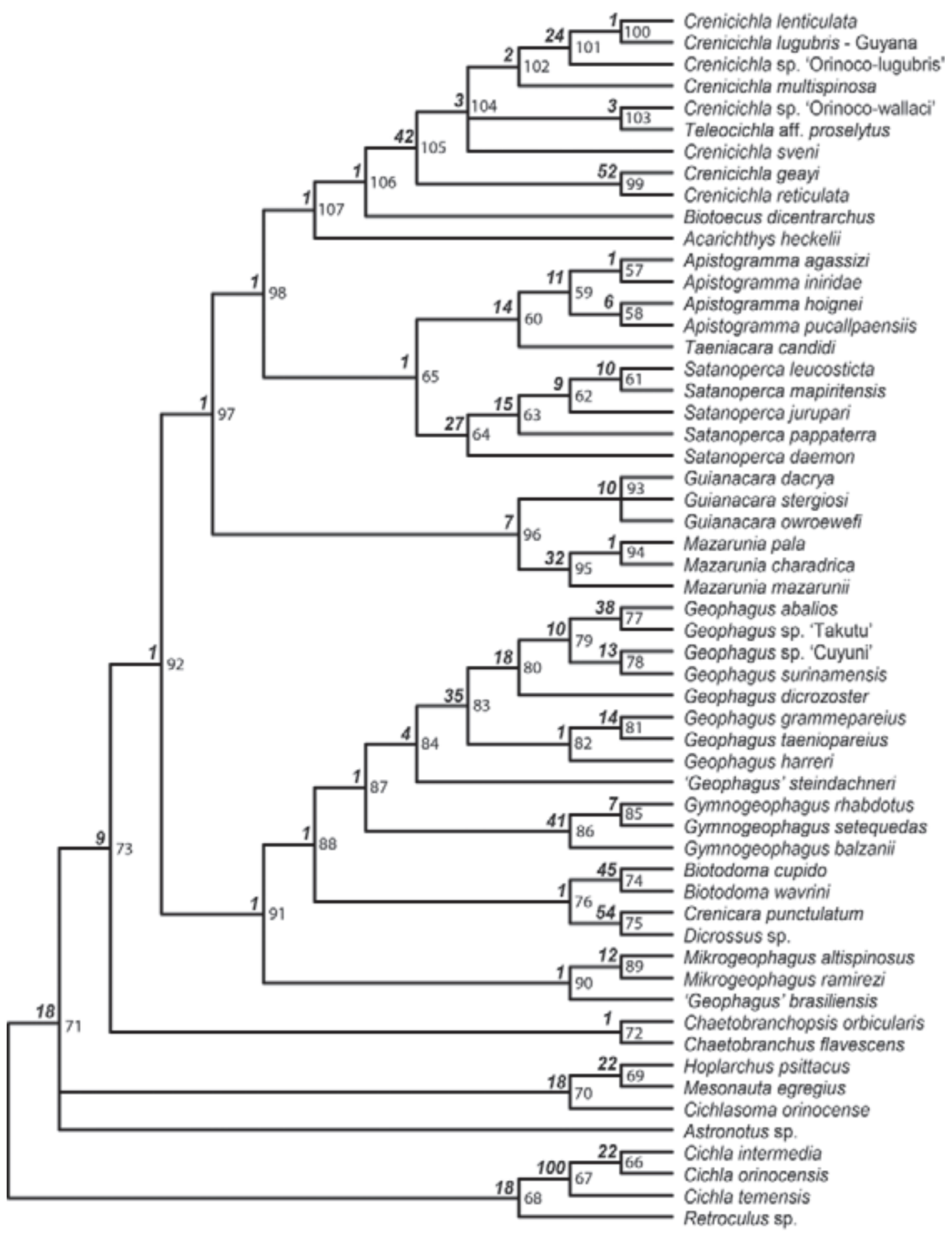

Fig. 1. Strict consensus tree of 8 most parsimonious trees 11073 steps obtained through combined analysis of 3868 base pairs from five loci and 136 morphological characters for 56 taxa. Consistency Index $=0.30$, Retention Index $=0.50$, Re-Scaled consistency index $=0.15$; Decay Index values indicated by each node. See Materials and Methods for details. 


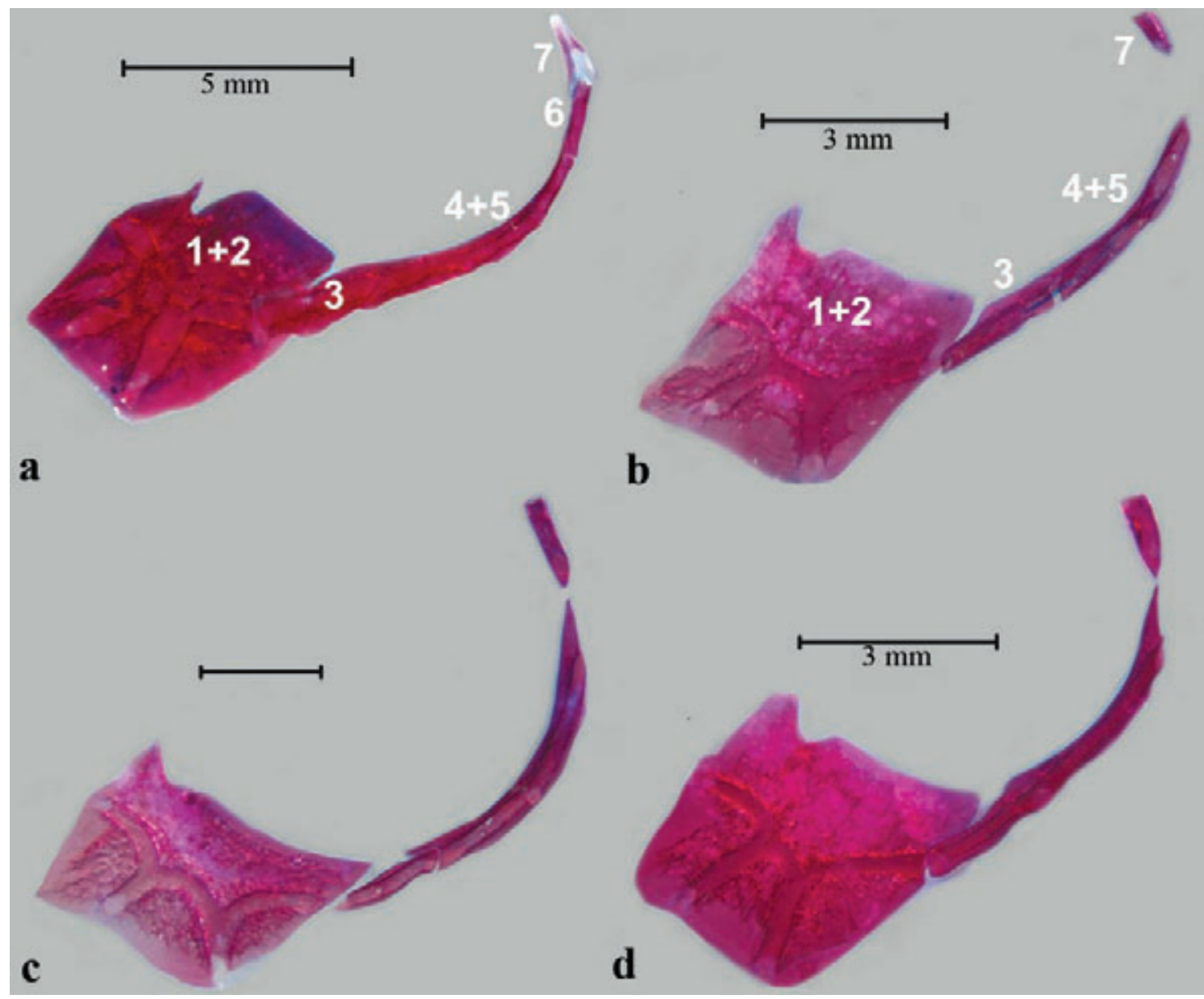

Fig. 2. Infraorbital series in left, lateral view, illustrating morphological character 116; a) Guianacara dacrya, character state 116-1, paratype, $58.0 \mathrm{~mm}$ SL, ANSP 179495; b) Mazarunia charadrica, character state 116-3, $56.0 \mathrm{~mm}$ SL, ROM 83808; c) Mazarunia mazarunii, character state 116-3, 50.1 mm SL, ROM 83869 d) Mazarunia pala, character state 116-3, 50.8 mm SL, ROM 83753.

1990: fig. 5 and López-Fernández et al. 2005: fig. 7D). Second, the epibranchial expansion in Crenicara is distal to the pharyngobranchial articulation and is not part of the articulation itself, resulting in a narrow cartilage base at the tip of the anterior arm at the articulation with pharyngobranchial 1 (see Kullander, 1990: fig. 5). Contrastingly, in Mazarunia mazarunii and M. pala, the expansion is more proximal to the pharyngobranchial articulation, and the cartilage cap is not restricted to the tip of the anterior arm, but rather appears to expand along the medial edge of the laminar expansion (Fig. 3d). This configuration of epibranchial 1 is not present in $M$. charadrica, in which the expansion is almost completely absent and there is a wider angle between the uncinate and anterior arms than either in Guianacara or in the other species of Mazarunia. Interestingly, the degree of variation for these characters within Mazarunia is not unlike the variation in the same characters within Crenicara. A comparison between epibranchial 1 of Crenicara punctulatum (Kullander, 1990: fig. 5) and C. latruncularium (LópezFernández et al., 2005: fig 7D) reveal similar patterns of variation to those observed among Mazarunia charadrica (Fig. 3b) and the other two species of Mazarunia (Fig. 3c-d).
This degree of variation among species and between genera suggests that variation in pharyngeal attributes is subject of extensive homoplasy.

Monophyly of Mazarunia was further supported by several non-unique character states that nonetheless aid in characterizing the genus. These include: a caudally scaled interopercle (5-1, and see Appendix 1 and López-Fernández et al., 2005, for variation of this character in other taxa); equally-sized scales in the lateral and ventral chest (21-1); the presence of only four laterosensory pores on the dentary (56-1); a simple disjunct canal pattern on the lateral line (57$1) ; 3$ scale rows between the upper lateral line and the origin of the dorsal fin (61-3); a posteroventral laminar palatine expansion that is well developed and contiguous with the anterodorsal margin of the ectopterygoid (92-2); absence of a suture between the hyomandibular and metapterygoid (95-1); and the absence of an interarcual cartilage (103-2).

Monophyly of Guianacara was supported by five nonunique morphological characters, including: four scale rows between the upper lateral line and the dorsal fin origin (61-4); a complete infraorbital stripe extending from the lower edge of the orbit to the preopercle (69-1); first dorsal-fin ray 
membranes black (75-1); an approximately triangular posteroventral palatine laminar expansion, with a gap between the lamina and the anterodorsal margin of the endopterygoid (92-1); and a reduced, anteriorly directed blunt process on the distal postcleithrum (114-2), although

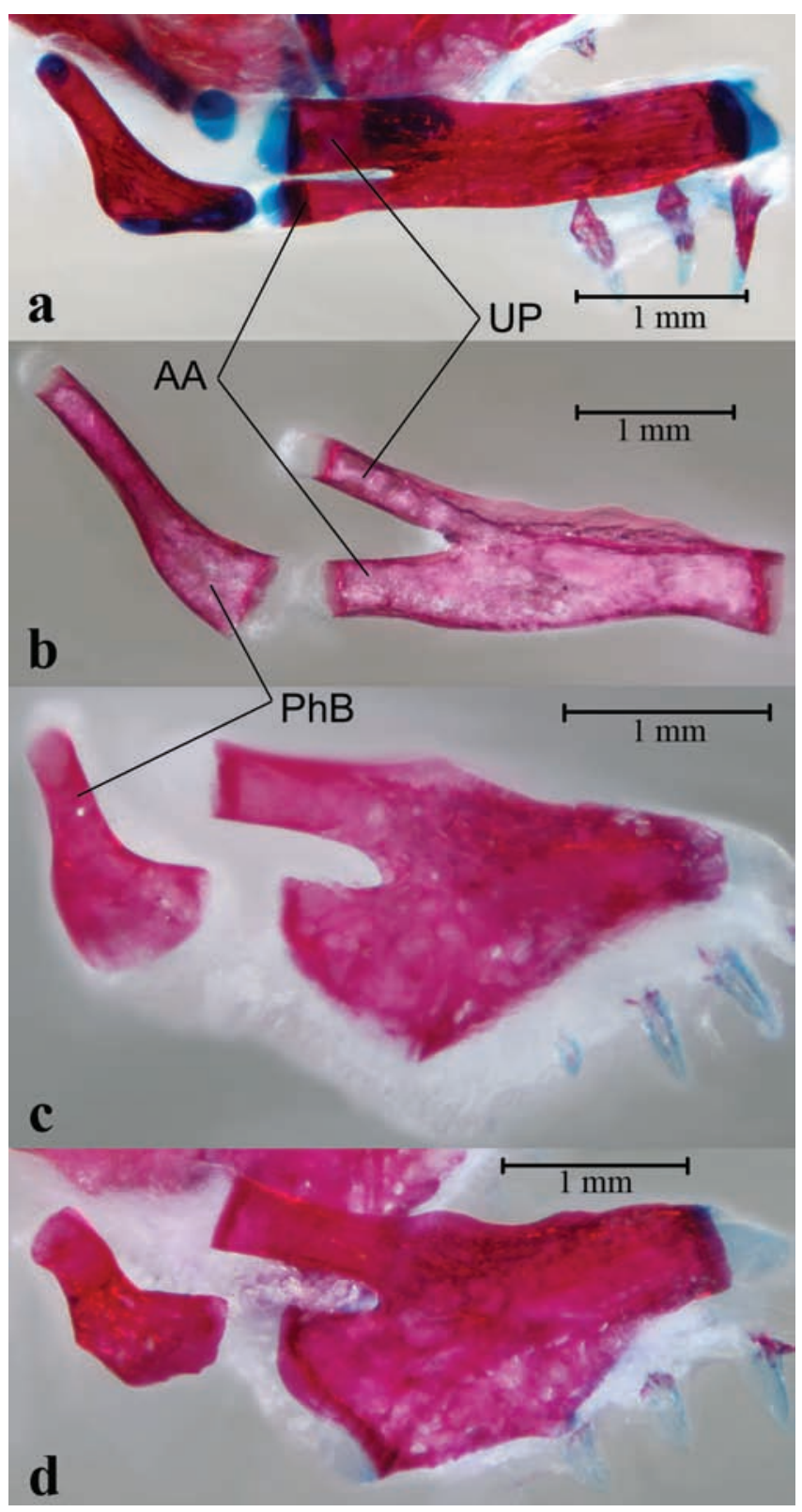

Fig. 3. First epibranchial and pharyngobranchial bones in right, approximately antero-dorsal view illustrating morphological phylogenetic characters 100 and 101 ; a) Guianacara dacrya, character states 100-0, 101-0, 58.0 mm SL, ANSP 179495; b) Mazarunia charadrica, character states 100-1, 101-2,56.0 mm SL, ROM 83808; c) Mazarunia mazarunii, character states 1002, 101-4, $50.1 \mathrm{~mm}$ SL, ROM 83869 d) Mazarunia pala, character states 102-0, 101-4, $50.8 \mathrm{~mm}$ SL, ROM 83753; UP, uncinate process of the first epibranchial; AA, anterior arm of the first epibranchial; $\mathrm{PhB}$, first pharyngobranchial. this character is reversed to state 0 (postcleithral process absent) in G. owroewefi.

Phylogenetic results strongly supported the sister-group relationship of Mazarunia and Guianacara. Morphologically, this relationship is based on eight non-unique synapomorphies that include uniserial inter-pelvic squamation (24-2); a simple disjunct trunk canal pattern in the lateral line (57-1, but can be polymorphic in some Guianacara species, see Appendix 1); absence of caudal peduncle spot (65-1); presence of a foramen on the lateral face of the ascending process of the premaxilla (89-1, except for M. mazarunii which has 2 foramina, 89-2); one concavity in the frayed zone of the fourth pharyngobranchial toothplate (113-2, but state 1 in Guianacara stergiosi); and third infraorbital tubular but with ventrally and dorsally directed laminar expansions (124-2, see Fig. 2, shared with Biotodoma).

\section{Mazarunia Kullander, 1990}

Mazarunia Kullander, 1990: 3-14 [type species: Mazarunia mazarunii by original designation; relationships to Dicrossus and Crenicara]. - Kullander, 2003: 638 [summary of type information, body size and distribution]. - LópezFernández et al., 2010: 1072, 1075, 1077, 1079-1081 [relationships within Neotropical cichlids and Geophagini (sensu López-Fernández et al., 2010), proposed sister relationship to Guianacara].

Diagnosis. Distinguished from all other genera in Geophagini, including its sister genus Guianacara, and all other cichlids by the unique loss of infraorbital 6 (Fig. 2a-d, Character 116-3, see Fig. 1, Appendix 3, and phylogenetic section above). Phylogenetic analysis revealed two other characters with unique states but are present only in two of the three species of Mazarunia: 1) in M. mazarunii and M. pala the anterior arm of the first epibranchial bone is wider than the uncinate process (Fig. 3c-d, 100-2); in M. charadrica, the uncinate process and the anterior arm are approximately of the same width (Fig. 3b, 100-1), which is a non-unique derived condition from that of the sister-genus Guianacara, in which the uncinate process is wider (Fig. 3a, 100-0). The above condition in M. mazarunii and M. pala is associated with an apparently unique medial, anteroventral expansion of the first epibranchial (Fig. 3c-d, 101-4, see above); the epibranchial expansion in M. charadrica is largely reduced (Fig. 3b, 101-2), its presence is a derived condition with respect to that in Guianacara (Fig. 3a, 101-0). Beyond the above unique or nearly unique conditions, Mazarunia can be further distinguished from all other cichlid genera by the combination of a large number of non-unique characters (see phylogenetic section above), including: 1 ) a caudally scaled interoperculum (5-1);2) equalsized scales in the ventral and lateral chest regions $(21-1) ; 3)$ a simple, disjunct pattern of lateral line squamation (57-1);4) a well-developed posteroventral lateral expansion of the palatine that is largely contiguous with the ectopterygoid $(92-2)$; 5) the absence of a suture between the hyomandibular 
and the metapterygoid $(95-1) ; 6)$ the absence of an interarcual cartilage (103-2); 7) smooth preopercle, supracleithrum and extrascapula; 8) 2-3 tooth plates on ceratobranchial 4. See also Kullander (1990) for other diagnostic characters based on the original description of Mazarunia mazarunii. All species of Mazarunia can be further distinguished from species of their sister-genus Guianacara by their distinct color patterns.

\section{Mazarunia mazarunii Kullander, 1990 Figs. 2c, 3c, 4, 5, $6 \mathrm{~b}$}

Mazarunia mazarunii Kullander 1990: 3-14 [original description; type species by original designation; relationships to Dicrossus and Crenicara]. - Kullander, 2003: 638 [summary of type information, body size and distribution]. - López-Fernández et al., 2010: 1072, 1075, 1077, 1079-1081 [relationships within Geophagini].

Diagnosis. Mazarunia mazarunii can be distinguished from all other cichlids by the generic diagnostic characters; additionally, phylogenetic analysis revealed that the species can be distinguished from all other species of Mazarunia by the autapomorphic presence of two foramina ( $v s$. one) on the lateral face of the ascending process of the premaxilla (89-2); a number of plesiomorphic characters in combination are also useful in the species diagnosis: lachrymal bone that is longer than deep (122-0, vs. deeper than long), and by an infraorbital 3 that is contiguous but not overlapping with the lachrymal (125-0, vs. overlapping, Fig. 2c). Externally, M. mazarunii can be distinguished from its congeners by the presence of ctenoid scales ( $v s$. cycloid) on the subopercle, interopercle and chest, and by unique characters of its coloration, including a complete suborbital stripe extending from the lower edge of the orbit to the interopercle, the presence of a supraorbital stripe directed caudad and for being the only Mazarunia species with a discernible lateral band formed by the mid-line blotching pattern associated with lateral bars. Finally, $M$. mazarunii has a black or dark bar from the occipital region, along the caudal margin of the opercle to the insertion of the pectoral fin, which in large adult individuals gives the impression of a collar (Figs. $4 a$ and 5a).

Description. Measurements are summarized in Table 1. No apparent sexual dimorphism. Head equal or slightly broader ventrally than dorsally. Dorsal head profile ascending, convex from tip of snout to insertion of dorsal fin; dorsal-fin base convex, horizontal to 10-11 spine, descending gently to last spine, then abruptly to last soft ray; dorsal caudal peduncle straight, descending to caudal-fin base. Ventral head profile straight or slightly convex, descending to pelvic-fin insetion; straight or slightly concave, horizontal to anal-fin insertion; anal-fin base convex, ascending; ventral caudal peduncle straight, ascending to caudal-fin base. Upper lip about half as wide as lower; lower lip uniformly wide, covering distal portion of upper lip when mouth closed. Lower lip fold broad, discontinuous at dentary symphysis. Maxilla reaching about one-half of distance between nostril and orbit. Opercle, preopercle, cleithrum, supracleithrum and post-temporal smooth.

E1 scales 24(1), 25(9), 26(3); upper lateral line scales 16(4), 17(4), 18(3), 19(2); lower lateral line scales 8(2), 9(11). Scales between dorsal-fin insertion and upper lateral line 3(5), 31/2(9); scales between caudal-most upper lateral line tubed scale and dorsal fin 1(2), 11/2(5), 2(6). Circumpeduncular scales ctenoid, 7 rows above and 7 below lower lateral line. Scale rows between lateral lines 2 . Opercle fully scaled, ctenoid; subopercle fully scaled, ctenoid; cheek fully scaled, cycloid; interopercle caudally scaled, ctenoid. Occipital and flank scales ctenoid. One column of postorbital scales, ctenoid. Lateral chest scales ctenoid, smaller than flank scales. Dorsal, anal, pectoral, and pelvic fin naked; caudal fin with single row of ctenoid scales between rays, covering basal one quarter to one third of fin length. Accessory caudal-fin extensions of lateral line restricted to one tubed scale at base of dorsal-fin between D3 and D4 and ventrally between V4 and V5 (and see Kullander, 1990).

Dorsal-fin rays XVI,6(1), XVI,7(1), XVI,8(1), XVII,7(4), XVII,8(5); anal III,7(3), III,8(7), IV,7(2), IV,8(1). Dorsal spines increasing in length from first to $6^{\text {th }}-7^{\text {th }}$, gradually decreasing to last; short membranous lappets behind all spines. Soft portion of dorsal fin rounded in smaller specimens $(<48.0 \mathrm{~mm}$ $\mathrm{SL})$, increasingly pointed in larger individuals, $2^{\text {nd }}$ to $4^{\text {th }}$ soft ray longest, not produced into filaments, not generally reaching caudal-fin base. Caudal fin symmetrical, distal margin slightly emarginated. Anal fin rounded, $4^{\text {th }}$ ray longest, not produced even in largest specimen $(76.7 \mathrm{~mm} \mathrm{SL})$, not reaching caudal-fin. Pectoral fin asymmetrical, slightly rounded dorsocaudally, $2^{\text {nd }}$ and $3^{\text {rd }}$ rays longest; longest rays not reaching anus. Pelvic fin triangular, spine about half length of first ray, which is longest, often produced into reaching up to $4^{\text {th }}$ analfin spine.

Premaxillary hemiseries in outer row with 6 to 12 thin, sharp, slightly recurved, unicuspid teeth, progressively smaller distally from symphysis. Three irregular rows of smaller, very thin, straight or very slightly recurved unicuspid teeth, separated from outermost row by wide gap. Dentary hemiseries with 18 to 20 teeth in outer row, size diminishing caudally such that anterior 6 are clearly larger than caudad ones. Two inner rows with smaller teeth, cylindrical, straight, unicuspid, separated from outer row by gap that disappears laterally, teeth eventually line up with smaller teeth of anterior row. Dentary and premaxillary hemiseries approximately continuous with each other, with no readily visible gap between them.

External rakers on first gill arch 11(6), 12(6), 13(1). Lower pharyngeal tooth plate (Fig. 6b) slightly wider than long, bone length about $90 \%$ of width; dentigerous area $87 \%$ of width, $76 \%$ of length; $13-15$ teeth in posterior row; 8-9 in median row. Lateral outer teeth unicuspid, cylindrical with recurved tips, progressively smaller caudally, larger medially; posteromedial larger, cylindrical, unicuspid, with medial cusps. Three tooth 
Table 1. Morphometric data for all species of Mazarunia $. \mathrm{SD}=$ Standard deviation; $\mathrm{N}=$ number of specimens

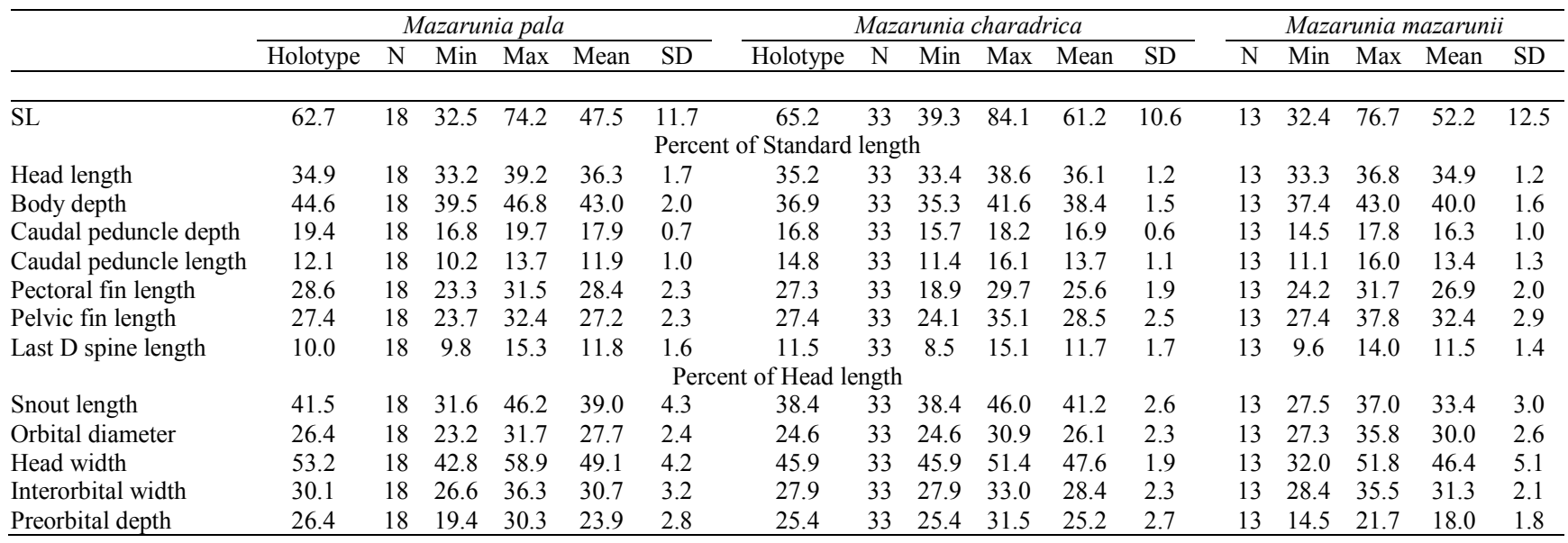

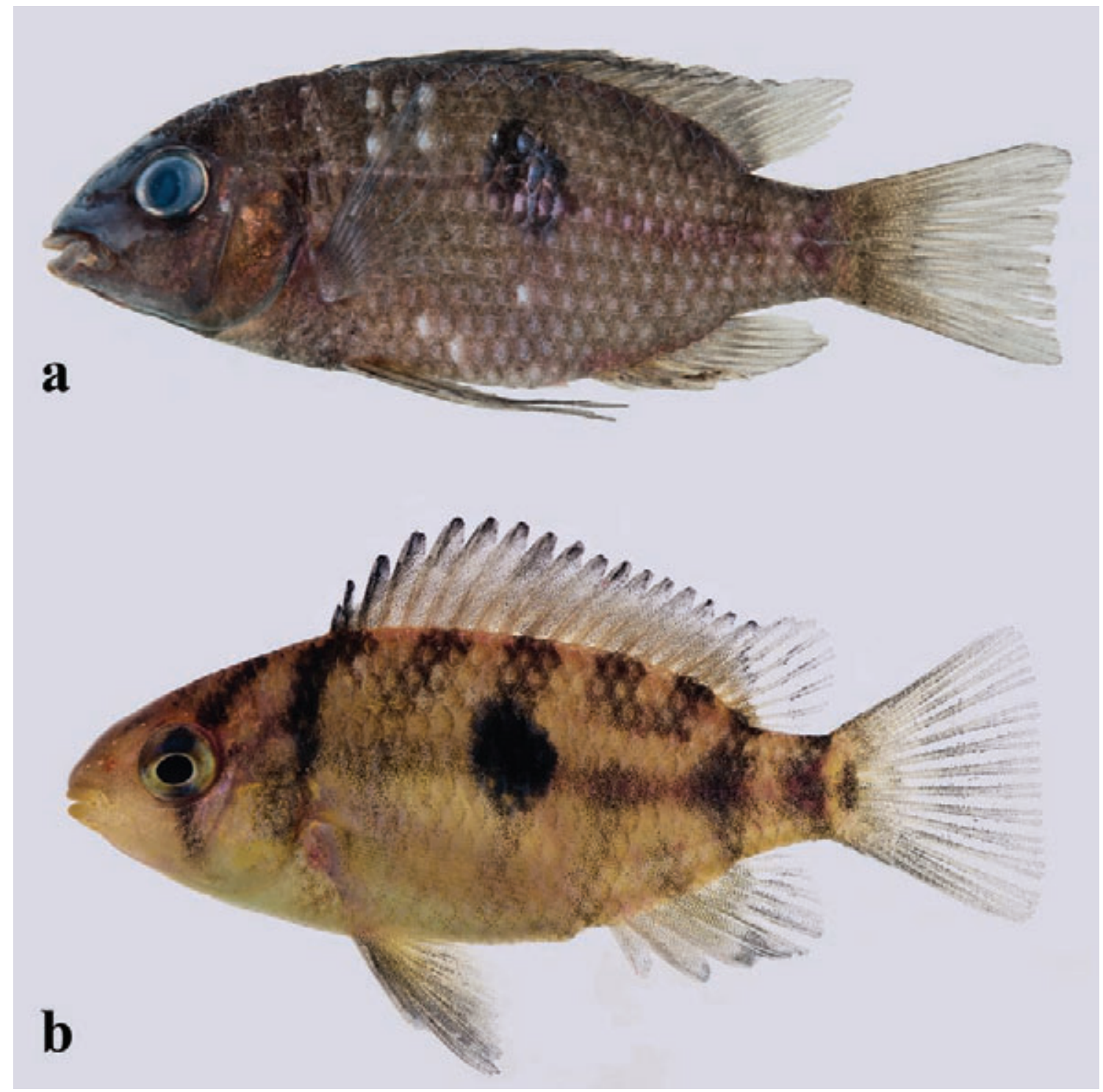

Fig. 4. Live colors of Mazarunia mazarunii through ontogeny; a) adult individual, probably male, $76.7 \mathrm{~mm}$ SL, ROM 89531 shortly after capture and anesthetized with clove oil, b) juvenile $38.1 \mathrm{~mm}$ SL, ROM 89609 shortly after capture. 
plates on fourth ceratobranchial. Vertebrae $12+14=26(1)$, $13+13=26(1), 13+14=27(5)$.

Color in life and in alcohol. See Kullander (1990) for full description of pigmentation pattern. Previous description herein expanded by incorporating larger adults up to $76.7 \mathrm{~mm}$
SL, largest known individual (ROM 89531). We comment on ontogenetic color variation (Figs. 4 and 5). Life and alcohol coloration treated together as most coloration is melanic and maintained after preservation. Exceptions are gill cover, which has coppery sheen in large adults (Fig. 4a), and base color tending to be lighter tan or pinkish color in live juveniles (Fig.

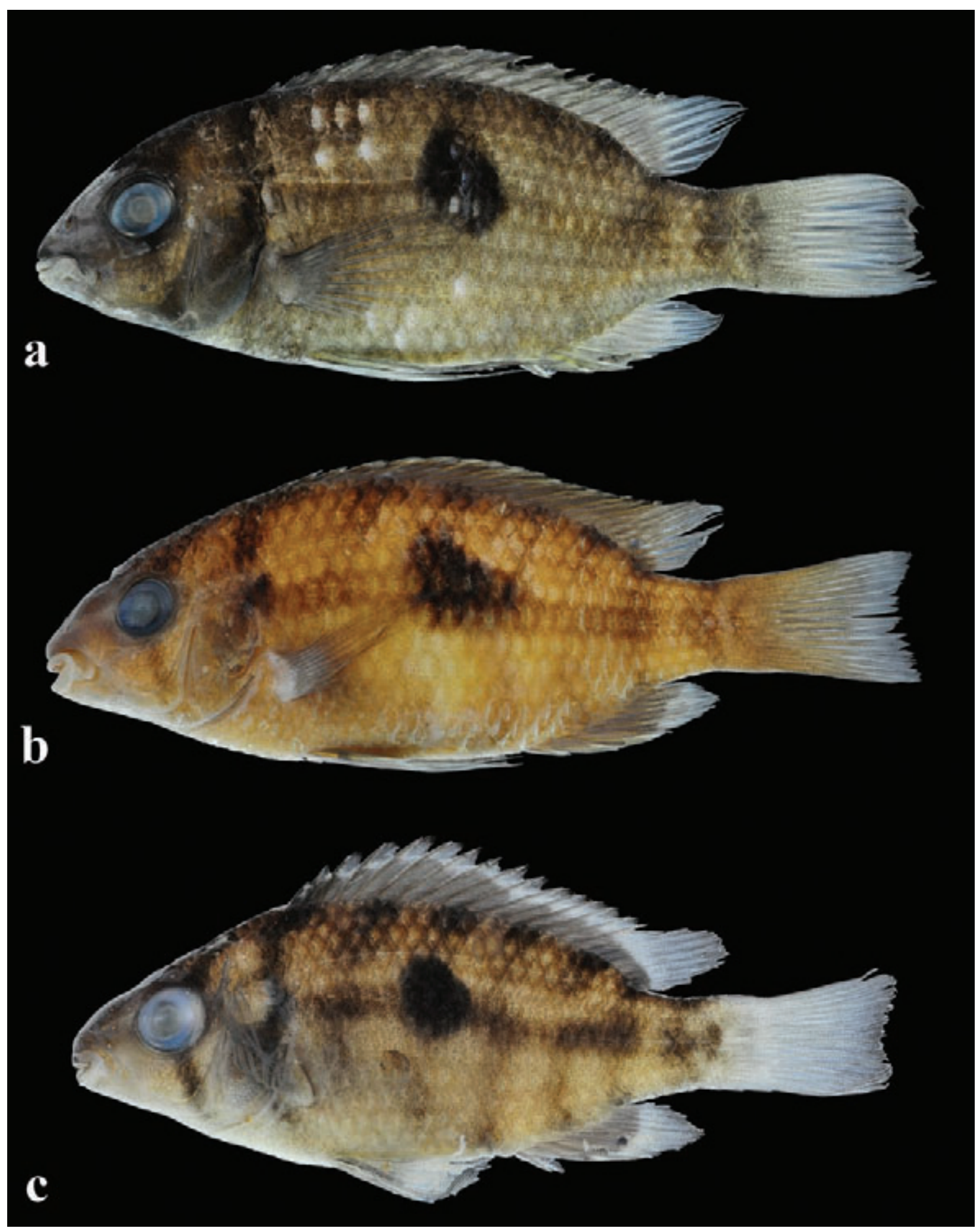

Fig. 5. Ontogenetic changes in body shape and coloration pattern in Mazarunia mazarunii; a) same adult individual as shown shortly after capture and anesthetized in Fig. 6a, 76.7 mm SL ROM 89531, b) 61.2 mm SL ROM 89586, c) 38.2 mm SL ROM 89522. 


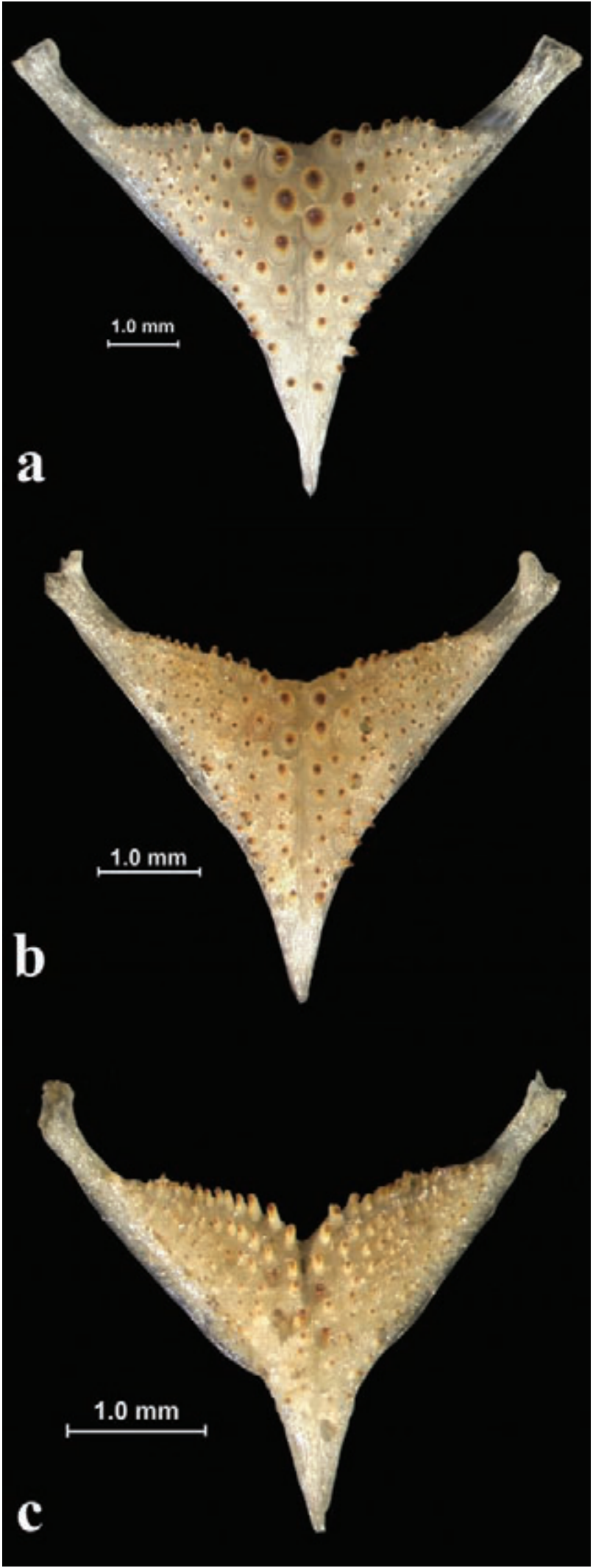

Fig. 6. Lower pharyngeal jaw of species of Mazarunia in occlusal view; a) Mazarunia charadrica, paratype, ROM 89553, 67.1 mm SL, b) Mazarunia mazarunii, ROM 83737, 58.5 mm SL, c) Mazarunia pala, paratype, ROM 83753, 43.8 mm SL. 4b). Base color grayish-beige, countershaded. Most flank scales in large adults with light centers and grey posterior edge, alignment giving impression of alternating rows of light spots with gray horizontal lines. Head with base color anterior to eye and immediately posterior of orbit; much darker in supraorbital area, making supraorbital bar less distinct. Infraorbital stripe less continuous than in smaller individuals, stronger at corner of preoperculum and at interoperculum, faded along cheek. Whitish stripe from anterior margin of orbit to nostril seen in juveniles changed into darker brown stripe over greyish-beige color of snout. Bar running from dorsal midline just anterior to dorsal-fin origin (Bar 7 in Kullander, 1990) descending vertical to upper lateral line, continuing on caudal edge of opercle, slightly lighter through interopercle and branchiostegal membrane giving impression of collar. Dark vertical bars of juveniles greatly reduced. Following Kullander's (1990) numbering system, bars 1 and 2 present as diffuse spots or blotches, bars 3 to 6 reduced to wide, faint spots at base of dorsal-fin; in some cases corresponding faint midlateral blotch variably present in bar 4; bar 5 extends ventrally, uniting with large, black midlateral spot, which is about 4 scales wide and 4 scales high; dorsal edge of midlateral spot includes scales of upper lateral line.

Geographic distribution. According to Kullander (1990), the two type specimens were collected from the blackwater Kamarang River, slightly up-stream of Kamarang (the town is located at the mouth of the Kamarang River where it joins the Mazaruni River). Additional localities from the Mazaruni River and Membaru Creek are shown in Fig. 7. Mazarunia mazarunii was most frequently found on sandy beaches, many

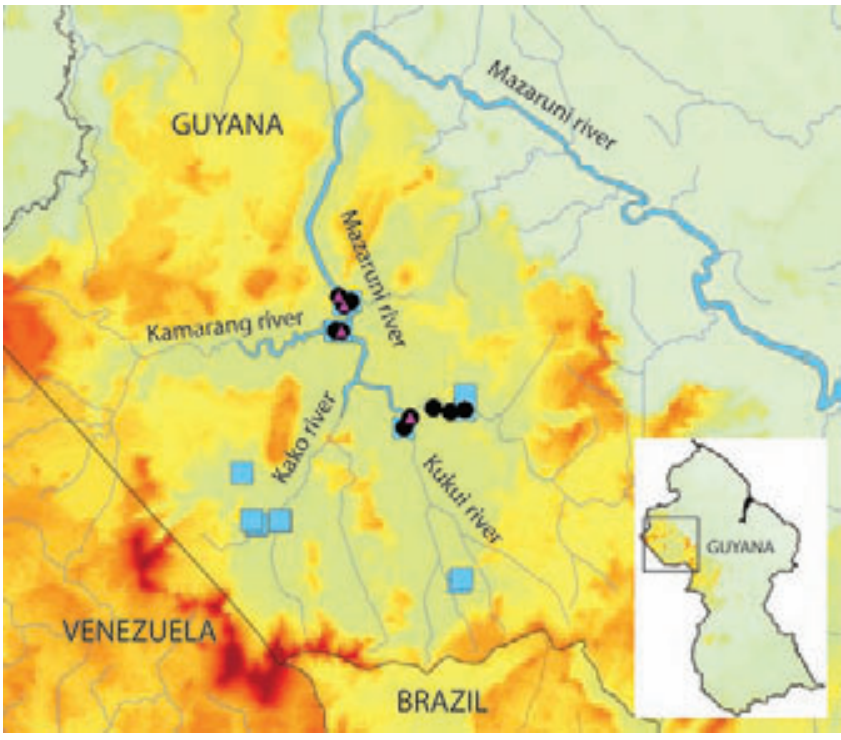

Fig. 7. Map of the upper Mazaruni River basin showing collection localities and known distribution of the three species of Mazarunia. Blue squares: Mazarunia charadrica, Black circles: Mazarunia mazarunii; Purple triangles: Mazarunia pala. One symbol may represent more than one collection locality. 
deposited by gold mining dredges, along the main channel of the Mazaruni River and its tributaries.

Habitat. Mazarunia mazarunii was collected mostly in or near the main upper Mazaruni River channel, generally in localities with sandy or slightly muddy substrates, some times with some structure formed by submerged or emerging grass and other riparian vegetation and some drift wood. At night all species of Mazarunia can move into shallow, flooded banks which can have substantial amounts of flooded terrestrial vegetation. All sites had black water with parameters typically ranging from $21.8-24.5^{\circ} \mathrm{C}$, high levels of dissolved oxygen between 5.2 and $9.3 \mathrm{mg} / \mathrm{L}$, acid pH of 4.0-4.8 and none to slow currents usually around $0-0.2 \mathrm{~m} / \mathrm{s}$, except for one locality where it reached $0.4 \mathrm{~m} / \mathrm{s}$. Conductivity was exceedingly low and ranging between $0-10 \mu \mathrm{S}$. The species was frequently caught in artificial gold-mining "tailings" beaches along the Mazaruni main channel; these sites tend to artificially have lower transparency $(0.2-0.3 \mathrm{~m}$ Secchi depth) than unaltered sites where the species is present (e.g. 0.6$0.85 \mathrm{~m}$ Secchi depth).

Material examined. Guyana, Cuyuni-Mazaruni (Region 7), upper Mazaruni River: ROM 83737, 1, 59.6 mm SL Mazaruni River, sandy beach at the confluence of the Mazaruni River and the Kukui River. ROM 83752, 2, 42.1 and $46.1 \mathrm{~mm} \mathrm{SL}$, Mazaruni River, sandy beach and associated embayment both created by gold-mining dredging. ROM 83864, 1, $47.3 \mathrm{~mm}$ SL, Membaru creek at an artificial sandy beach. ROM 83869, 4, 40.5-48.5 mm SL, Mazaruni River, beach downstream from Kamarang. ROM 89522, 5, 35.2$42.7 \mathrm{~mm}$ SL (1, $35.6 \mathrm{~mm}$ SL), Kamarang River, beach on left bank, just downstream from Kelly Kramer's house. ROM 89531, 2, 32.4 and $76.7 \mathrm{~mm}$ SL, Mazaruni River, backwater channel behind beach sampled at HLF11-06, $2 \mathrm{~km}$ downstream from site 5. ROM 89551, 2, 46.8 and $29.6 \mathrm{~mm} \mathrm{SL}$, Mazaruni River, main channel on a mine tailings beach just downstream from Abbou Creek on left bank. ROM 89586, 5, 48.1-63.1 mm SL, Kamarang River, outside Kelly Kramer's house. ROM 89609, 2, 26.4-38.1 mm SL, Mazaruni River, channel at backwaters about $50 \mathrm{~m}$ behind HLF11-04. ROM 89674,
1, $42.0 \mathrm{~mm}$ SL, Mazaruni River, backwater channel on right bank in front of Warwata village, near mouth of Kamarang River. ROM 89745, 10, 29.8-47.4 mm SL, Mazaruni River, channel on left bank, downstream from Kamarang, $1 \mathrm{~km}$ upstream from Membaru.

\section{Mazarunia charadrica new species} Figs. 2b, 3b, 6a, 8-10

Mazarunia sp. 1 López-Fernández et al., 2010: 1072, 1075, 1077, 1079-1081 [relationships within Geophagini].

Holotype. UG/CSBD 1667, (ex-ROM 83808), 65.2 mm SL, Guyana, Cuyuni-Mazaruni (Region 7), upper Mazaruni River, Waruma Creek, shallow pool at HLF08-19, between 2-10m wide by about 20m long, 5²8’31.8’N, 6046'46.812”W, 21 Apr 2008, H. LópezFernández, D. C. Taphorn, E. Liverpool, C. Thierens \& K. Kramer.

Paratypes. Guyana, upper Mazaruni River, Cuyuni-Mazaruni (Region 7): ROM 83687, 2, 22.0-24.7 mm SL, Kukui River, upstream of Philipai, 5²2'5.304'N, 60²1'59.1114'W, 16 Apr 2008, H. López-Fernández, D. C. Taphorn, E. Liverpool \& C. Thierens. ROM 83693, 11, 52.0-66.0 mm SL, Kukui River, in and around Philipai, 5²1'37.116”N, 60²2'18.408'W, 16 Apr 2008, D. C. Taphorn, E. Liverpool, C. Thierens \& local fisherman. ROM 83705, 8, 20.4-78.5 mm SL (1, 77.6 mm SL), Kukui River, day sample around Philipai, 5²1'37.116”N, 60²2'18.408”W, 16 Apr 2008, H. López-Fernández, D. C. Taphorn, E. Liverpool \& C. Thierens. ROM 83709, 16, 21.9-67.0 mm SL (1, 57.8 mm SL), Kukui River, upstream around the camp on Philipai, $5^{\circ} 21^{\prime} 37.116^{\prime \prime} \mathrm{N}$, 60²2'18.408”W, 17 Apr 2008, H. López-Fernández, D. C. Taphorn, E. Liverpool, K. Kramer \& C. Thierens. ROM 83741, 1, $16.97 \mathrm{~mm}$ SL, Mazaruni River, sandy beach at the confluence of the Mazaruni River and the Kukui River, 5 ${ }^{\circ} 40^{\prime} 21.2154^{\prime} \mathrm{N}$, 60²8'58.5834"W, 17 Apr 2008, H. López-Fernández, D. C. Taphorn, E. Liverpool, C. Thierens \& K. Kramer. ROM 83781, 6, 49.7-83.1 mm SL (all measured), Waruma Creek at campsite, 5²8'40.2954”N, 6046’45.2994”W, 20 Apr 2008, H. LópezFernández, D.C. Taphorn, E. Liverpool, C. Thierens \& K. Kramer. ROM 83796, 1, 42.2 mm SL, Waruma Creek, down stream from camp at the complex of riffles and shallow, semi-isolated pools, 5²9'9.816”N, 6047'22.416”W, 21 Apr 2008, H. López-

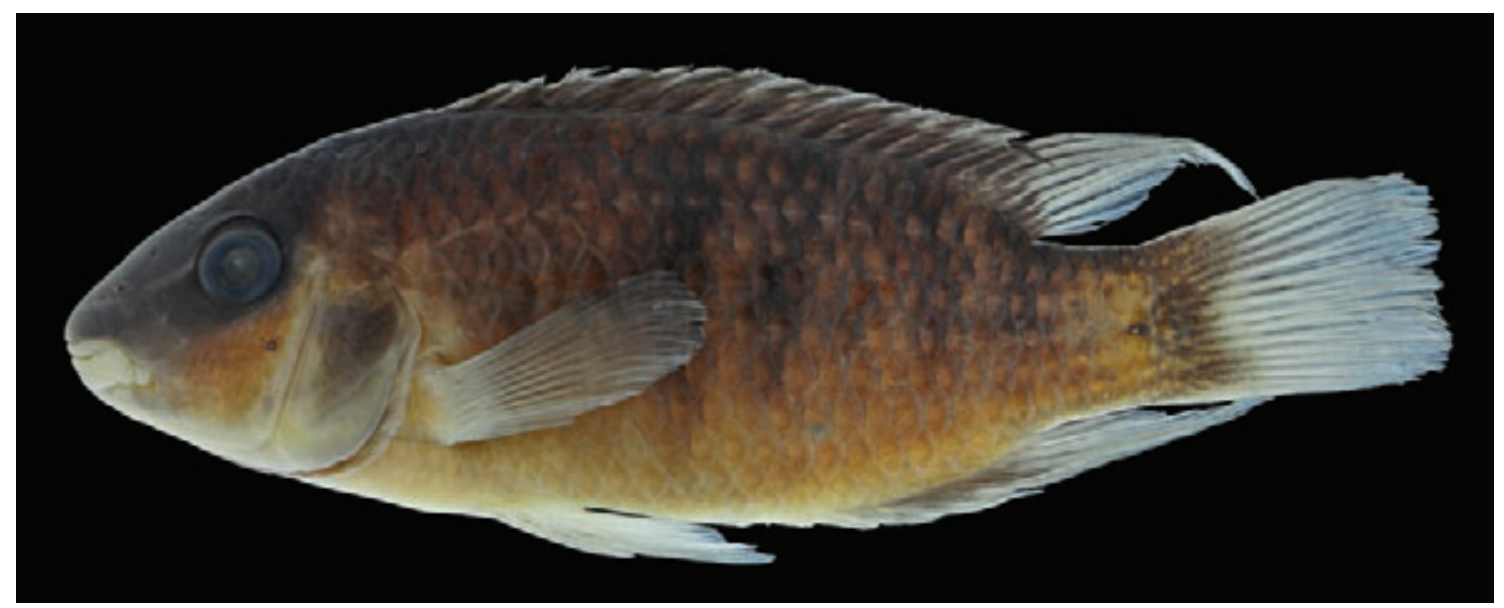

Fig. 8. Mazarunia charadrica, holotype, UG/CSBD 1667, 65.2 mm SL, Guyana, Cuyuni-Mazaruni (Region 7), Waruma Creek, tributary of Kako River, upper Mazaruni River drainage. 
Fernández, D.C. Taphorn, E. Liverpool, C. Thierens \& K. Kramer. ROM 83808, 17, 20.9-65.1 mm SL, same as holotype; ROM 83825, 3 , 19.5-25.5, Paikwa River rapids, $5^{\circ} 28^{\prime} 59.916^{\prime \prime} \mathrm{N}$, 6043'55.704'W, 22 Apr 2008, H. López-Fernández, D. C. Taphorn \& E. Liverpool. ROM 83840, 1, $53.4 \mathrm{~mm}$ SL (1,54.0 mm SL), Paikwa River rapids, 5²9'10.392”N, 6043'57.1074”W, 22 Apr 2008, H. López-Fernández, D. C. Taphorn \& E. Liverpool. ROM 83863 , 2, 76.7-76.8 mm SL (all measured), Membaru creek, at an artificial sandy beach, 555'33.996”N, 60³5'26.808”'W, 23 Apr 2008, H. López-Fernández, D. C. Taphorn \& E. Liverpool. ROM 89535, 15, 32.5-68.5 mm SL (3, 48.8-53.8), Kamarang River, beach on left bank, just downstream from Kelly Kramer's house, 551'59.5002'N, 60³7'14.4984'W, 14 Mar 2011, H. LópezFernández, S. Refvik, D. C. Taphorn, E. Liverpool, K. Kramer \& G. Kramer. ROM 89553, 78, 20.9-70.2 mm SL (5, 45.0-68.1 mm SL), Kamarang River, near its mouth at Kelly Kramer's house (Kelly Landing), 551'59.5002”N, 60³7'14.4984”W, 12 Mar 2011, E. Liverpool, H. López-Fernández, D. C. Taphorn \& S. Refvik. ROM 89559, 1, 29.7 mm SL, Mazaruni River, main channel on a mine tailings beach just downstream from Abbou Creek on left bank, 542’30.4554’'N, 60²1'39.564’'W, 4 Mar 2011, D. C. Taphorn, E. Liverpool, H. López-Fernández \& S. Refvik. ROM 89585, 2, 68.671.0 mm SL (1, 66.9 mm SL), Kamarang River, outside Kelly Kramer's house, 551'59.5002'N, 60³7'14.4984'W, various dates between 2008-2011, K. Kramer. ROM 89622, 2, 38.8-42.8 mm SL, Waruma Creek, riffles and shallow rapids upstream from camp, 5²8’31.8”N, 6046’46.812”W, 11 Mar 2011, H. López-Fernández, D. C. Taphorn, E. Liverpool \& S. Refvik. ROM 89644, 1, $41.8 \mathrm{~mm}$ SL, Sandaa Creek, run between the lowermost and second set of rapids, 5³4'52.7514”N, 6048’31.1034'”, 9 Mar 2011, D. C. Taphorn, E. Liverpool, H. López-Fernández \& S. Refvik. ROM 89647, 3, 35.3-53.1 mm SL (1, 52.0 mm SL), Mazaruni River at Kamarang, 15 Mar 2011, D. C. Taphorn, E. Liverpool, H. LópezFernández \& S. Refvik. ROM 89659, 6, 32.7-58.6 mm SL (1, 50.0 $\mathrm{mm}$ SL), Mazaruni River, Warwata village, near mouth of Kamarang River, 555'1.776”N, 60³6'13.4994”W, 16 Mar 2011, D. C. Taphorn, E. Liverpool, H. López-Fernández \& S. Refvik. ROM 89673, 6, 42.9-55.3 mm SL (1, 55.0 mm SL), Mazaruni River, backwater channel on right bank in front of Warwata village, near mouth of Kamarang River, 24 Mar 2011, H. López-Fernández, D. C. Taphorn \& E. Liverpool. ROM 89697, 3, 51.5-65.2 mm SL (3, 50.0-63.4 mm SL), Abbou Creek, approx. $1.2 \mathrm{~km}$ walking E from camp, 544'10.4274'N, 60²1'34.416”W, 5 Mar 2011, H. LópezFernández, D. C. Taphorn \& E. Liverpool. ROM 89701, 2, 59.3$70.7 \mathrm{~mm}$ SL (2, 59.6-68.3 mm SL), Sanda Creek tributary about 500 m downstream from HLF11-17, 9 Mar 2011, H. López-Fernández, D. C. Taphorn, E. Liverpool \& S. Refvik. ROM 89703, 13, 48.770.9 mm SL (1, 69.6 mm SL), Kamarang River, right bank, across the channel from Kelly Kramer's house, 551'59.5002'N, 60³7'14.4984'W, 12 Mar 2011, E. Liverpool \& D.C. Taphorn. ROM 89735, 2, 69.7-74.2 mm SL (2, 69.5-73.9 mm SL), Mazaruni River, river channel on right bank, across from HLF11-29, 5 55'1.776”N, 60³6'13.4994”'W, 13 Mar 2011, D. C. Taphorn, H. López-Fernández, E. Liverpool \& S. Refvik. ROM 89749, 2, 40.3-64.3 mm SL (all measured), Mazaruni River, channel on left bank, downstream from Kamarang, $1 \mathrm{~km}$ upstream from Membaru, 555'1.776”N, 60³6'13.4994”W, 13 Mar 2011, H. LópezFernández, D. C. Taphorn, E. Liverpool, S. Refvik \& K. Kramer. ANSP 192031 (ex. ROM 89553), 5, 46.1-64.7 mm SL, Kamarang River, near its mouth at Kelly Kramer's house (Kelly Landing), 551'59.5002'N, 60³7'14.4984'W, 12 Mar 2011, E. Liverpool, H. López-Fernández, D. C. Taphorn \& S. Refvik.
Diagnosis. Mazarunia charadrica can be distinguished from all other cichlids by the generic diagnostic characters. Phylogenetic analysis indicates it can be distinguished from the other species of Mazarunia by the apomorphic structure of its first epibranchial bone (100-1: uncinate process and anterior arm of approximately equal width and 101-2: reduced anteroventral expansion vs. uncinate process narrower and complete anteroventral expansion in M. mazarunii and $M$. pala); a dorso-ventrally flattened maxillary process of the palatine is a plesiomorphic condition restricted to $M$. mazarunii (vs. palatine maxillary process cylindrical in the other two species). Externally, M. charadrica is distinguished by having cycloid scales in the opercular, postorbital, lateral chest and anal-genital regions ( $v s$. ctenoid in the other species). $M$. charadrica is further diagnosed by the lack of infraorbital and supraorbital bars present in M. mazarunii and the mid-lateral spot present in both $M$. mazarunii and $M$. pala. In $M$. charadrica the supraorbital stripe is diffuse and expanded into a dark area that covers the dorsal portion of the head in an ascending line from the lower lip to the ventral edge of the orbit and from there to a point about mid-way between the posterior edge of the orbit to the insertion of the dorsal fin, giving the impression that the fish has a "black cap" (Figs. 8-10). M. charadrica has a unique pattern of seven vertical bars which are most obvious in juveniles but are not completely lost in adults. Bars 3-6 in antero-caudal direction are most visible in juveniles and medium-sized specimens but become fainter and almost disappear in adults. Many specimens show only bar number 3 (midlateral bar).

Description. Measurements are summarized in Table 1. Males with relatively small nuchal hump anterior to first dorsal-fin spine, possibly with longer dorsal and anal-fin filaments. Head slightly broader ventrally. Mouth subterminal. Dorsal head profile gently convex, from tip of snout to dorsal-fin origin; dorsal base slightly convex, descending gently to last dorsalfin spine, then steeply to dorsal-fin caudal insertion; dorsal caudal peduncle straight or slightly convex to caudal-fin base. Ventral head profile straight or lightly convex, descending to vertical line from pectoral-fin base; flat or slightly convex to anal-fin origin; anal-fin base straight, ascending; ventral caudal peduncle profile slightly concave, ascending caudalfin base. Tip of snout slightly anterior to upper lip in some specimens; upper lip about half as wide as lower; lower lip widest caudally, sometimes covering caudal-most edge of upper lip when mouth closed. Lower lip fold broad, discontinuous at dentary symphysis. Maxilla reaching from one third to less than one half distance between nostril and orbit. Opercle, preopercle, cleithrum, supracleithrum and posttemporal smooth.

E1 24(3), 25(27)*, 26(4); scales between upper lateral line and dorsal fin $3(11)^{*}, 3 \frac{1}{2}(23)$ anteriorly and $1(4), 1 \frac{1}{2}(30)^{*}$ posteriorly. Scales on upper lateral line 15(2), 16(12), 17(15)*, 18(5), and lower lateral line 7(6), 8(20)*, 9(8). Circumpeduncular scale rows 7 above, 7 below lower lateral line, ctenoid. Scale rows between lateral lines 2 . Opercle, subopercle and cheek 
fully scaled, cycloid or slightly ctenoid; interopercle caudally scaled, cycloid. Occipital and flank scales ctenoid. One column of postorbital scales, cycloid. Lateral chest scales cycloid, smaller than flank scales. Dorsal, anal, pectoral and pelvic fin naked; caudal fin with row of ctenoid scales between rays to one third of fin length. Accessory caudal-fin extensions of lateral line restricted to one tubed scale at base of dorsalfin between D3 and D4 and ventrally between V4 and V5.

Dorsal fin XV,8(1), XVI,8(28)*, XVII,8(5); anal fin III,7(6)*,
III, 8(28). Dorsal spines increasing in length from first to about $7^{\text {th }}-8^{\text {th }}$, then decreasing slightly; last spine about two thirds of first ray length, about half length of longest soft ray; membranous lappets behind all spines. Soft portion of dorsal fin pointed, $4^{\text {th }}$ ray longest, sometimes slightly produced as filament reaching one third to half of caudal fin length, especially in males with nuchal humps. Caudal fin symmetrical, distal margin almost straight, indented slightly at middle caudal-fin rays. Anal fin pointed, $3^{\text {rd }}-4^{\text {th }}$ rays longest,

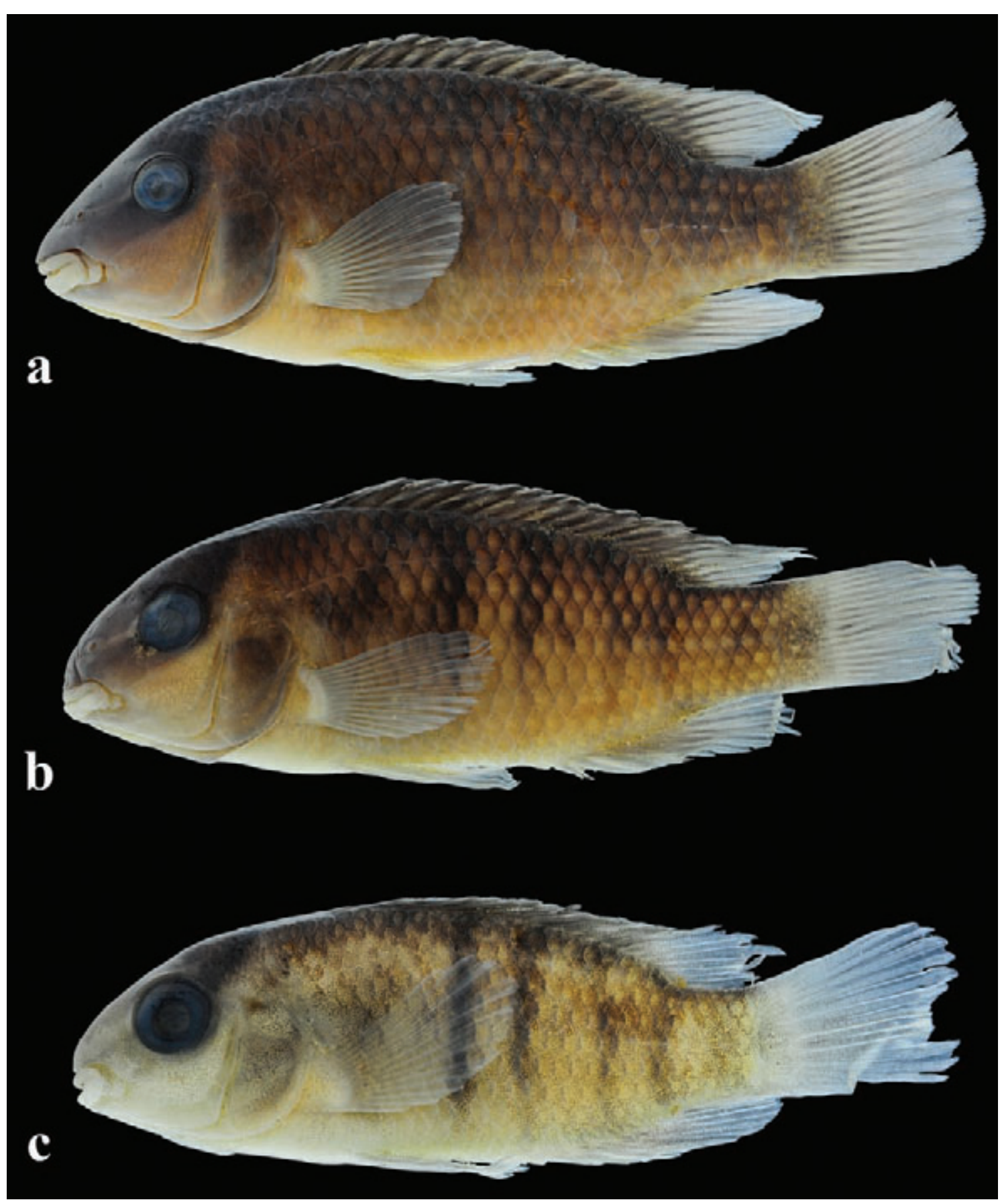

Fig. 9. Mazarunia charadrica, ontogenetic changes in overall body shape and melanic coloration; a) adult, $67.2 \mathrm{~mm}$ SL, b) young adult, $45.3 \mathrm{~mm} \mathrm{SL}$, c) juvenile, $21.9 \mathrm{~mm}$ SL. All specimens from ROM 83709. 
sometimes extended as filaments, reaching up to half caudalfin length. Pectoral fin asymmetrical, rounded dorsally, more or less straight ventrally from $4^{\text {th }}$ ray, which is longest; longest rays not reaching pelvic-fin or anus. Pelvic-fin spine shorter than first ray which is longest, barely reaching anus unless produced into filament, which may reach $1^{\text {st }}$ anal spine; each subsequent pelvic-fin ray shorter till last, which is about half length of longest.

Outer premaxilla hemiseries with 7-8 teeth, progressively smaller distally from symphysis. Three irregular rows of much smaller, unicuspid teeth, separated from outermost row by gap. Dentary hemiseries with 11-16 thin, sharp, slightly recurved, unicuspid teeth in outer row, two irregular inner rows with much smaller teeth separated from outermost row by gap, widest anteriorly and progressively narrow caudally. Dentary hemiseries separated by small symphyseal gap, particularly in outermost row.

External rakers on first gill arch 8(1), 9(6), 10(23)*, 11(4). Lower pharyngeal tooth plate wider than long, length of bone $79 \%$ of width; dentigerous area $66 \%$ of width, $62 \%$ of length; 9-12 teeth in posterior row; 5-7 in median row. Lateral outer teeth unicuspid, cylindrical, slightly recurved, progressively smaller caudally, larger medially; posteromedial teeth much larger, molariform, unicuspid, with medial cusps slightly curved anteriorly (Fig. 6a). Two tooth plates on fourth ceratobranchial. Vertebrae. $12+14=26(9)$. One supraneural bone.

Color in alcohol. Figs. 8-9. Base color pinkish brown to beige; snout, region between posterior margin of maxilla to eye and top of head near supraoccipital dark brown or gray. Lips light gray. Side of head, throat, interopercle, lower region of preopercle and chest light beige; gill cover with brown-black blotch, most pronounced dorsally. Infraorbital stripe absent; supraorbital stripe present, directed caudad, distinct in small juveniles (Fig. 9c), progressively expanding with growth until forming dark "cap" extending diagonally from dorsal midline caudad to orbit to caudo-ventral margin of orbit and then to corner of mouth (Fig. 9a-b); groove from posterior margin of nare to anterior margin of eye light beige. Branchiostegal membrane brown, greatly contrasting with light chest. Body counter shaded, darkest at dorsal midline, most scales outlined with gray to black, outlines darker and thicker dorsally, lightest below pectoral fin; centers of scales light, forming rows of light spots, most notable on caudal peduncle. Flanks with seven vertical bars, variably expressed, most obvious in juveniles but not completely lost in many adults (including holotype). Anteriormost bar coincides with dorsal fin insertion, continuous with gill cover blotch in larger individuals (Fig. 9a), but separated by lighter area in smaller specimens (Fig. $9 \mathrm{~b}-\mathrm{c})$; second bar extending anteroventrally from about $4^{\text {th }}$ and $5^{\text {th }}$ dorsal spines to E1, forming broad "U-shape" with first bar just caudad of postcleithrum; third bar approximately between $7^{\text {th }}$ and $9^{\text {th }}$ dorsal spines, 2 scales wide, extending vertically under pectoral fin to $\mathrm{H} 2$, or reaching $\mathrm{H} 4$ in smaller juveniles (Fig. 9c); fourth bar approximately below $12^{\text {th }}$ to $14^{\text {th }}$ dorsal-fin spines, two scales wide, extending ventrally, slightly caudad to posterior edge of pectoral-fin to E0 in small adults, to $\mathrm{H} 2$ in small juveniles; fifth bar below last two dorsal spines and first soft ray, two scales wide dorsally, extending slightly caudally to E1 then slightly rostrally to $\mathrm{H} 1$; sixth bar below caudal insertion of dorsal fin, about two scales wide, extending antero-ventrally to E0, then caudo-ventrally to $\mathrm{H} 1$, forming "H-figure" with fifth bar; seventh bar most noticeable on E0, forming faint blotch in middle of caudal peduncle, about 1-1 1/2 scales wide and deep. Bars 3-6 most visible in juveniles and medium-sized specimens (Fig. 9b-c), tend to almost disappear in larger adults (Fig. 9a). Many specimens show only bar 3 (midlateral bar). Spinous portion of dorsal fin and base of soft portion black, rest of fin plain, dusky gray. Caudal fin gray, rays lighter than membranes. Anal fin gray, darker pigment along rays. Pelvic fin gray, first rays darkest.

Color in life. From photographs of live and freshly preserved specimens (Fig. 10). Melanic coloration as for preserved specimens. Background color pinkish-tan to purple, most scales with lighter centers, often forming horizontal rows of light spots, and reticulate pattern on sides, more apparent posteriorly. Head from tip of snout above eye and posterior to tip of supraoccipital dark brown to gray, anteriorly tapering light stripe from dorsal anterior margin of eye to posterior

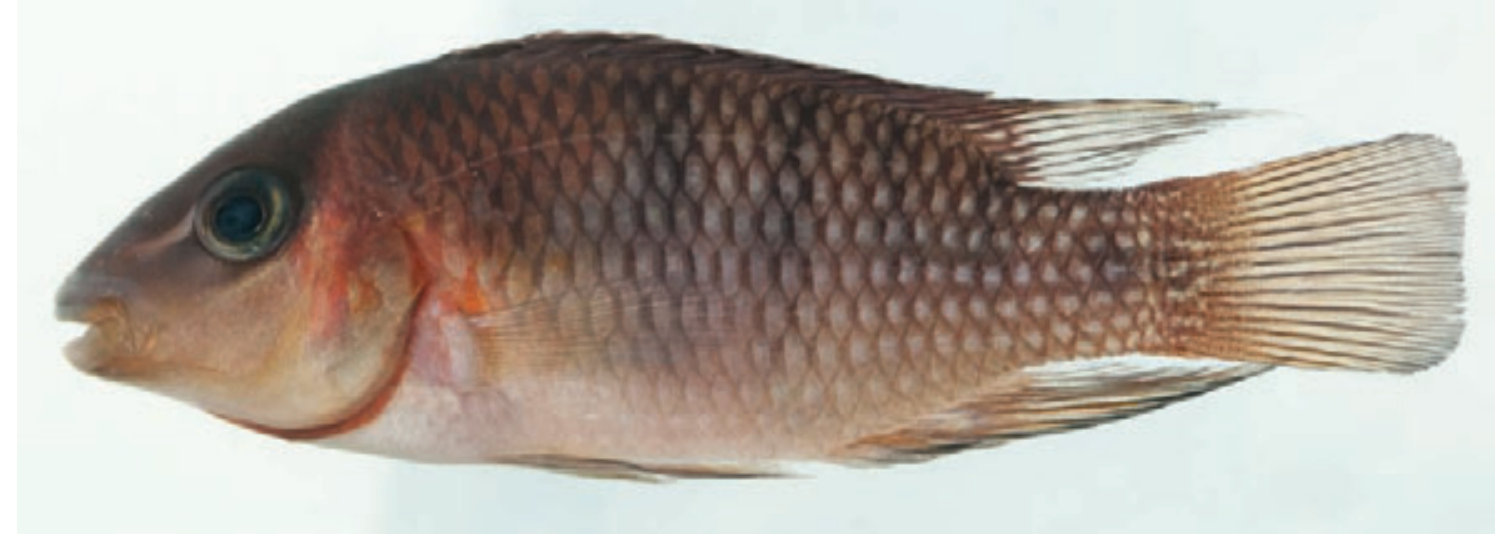

Fig. 10. Mazarunia charadrica, $65.0 \mathrm{~mm}$ SL, ROM 89553, live coloration in a specimen from the Kamarang River, photographed shortly after capture. 
naris. Iris greenish with golden highlights. Upper lip brown at tip, white laterally, lower lip white. Head below eye bright pink, yellow or orange, extending onto opercle and sides of body posterior to opercle and anterior to pectoral-fin base. Pink or orange coloration extending more or less continuously to bright orange blotch just dorsal to insertion of pectoral fin. Branchiostegal membrane pink to orange or maroon. White on ventral portion of head and ventrum between pectoral-fin base and posteriorly onto abdomen. Dorsal fin gray to maroon brown on spinous portion and base of soft rays, rest of soft portion hyaline or slightly dusky. Anal-fin spines blackish gray, soft rays pink to maroon, membranes lighter. Pectoral fin transparent, rays thinly outlined with black. Pelvic whitish, anterior rays outlined in black. Caudal fin dusky gray, membranes weakly pink.

Geographic distribution. Mazarunia charadrica has the broadest distribution of all species in the genus, known from the upper Mazaruni River main channel, its direct tributaries, the Kamarang and Kukui Rivers and Abbou creek, and from several tributaries of the Kako River, including Waruma, Sandaa and Paikwa creeks. It is presumably present in the Kako River itself, but conditions in the field prevented us from performing collections. Areas without sites on the map have not been sampled by ichthyologists, but we expect the species to be present in all upper Mazaruni tributaries (Fig. 7).

Etymology. From the Greek charadra $(\chi \alpha \rho \alpha \delta \rho \alpha)$, a mountain stream or a torrent. In reference to its apparent preference for reophilous habitats; the species is often found in the steep tributaries of the Mazaruni River that flow from the slopes of the Roraima massif and other mountainous sources in the area. To be regarded as an adjective in feminine form.

Habitat. Mazarunia charadrica is the most reophilic of all three species. Although it can be collected with the other species in main channel sites with sandy bottoms and sluggish currents, this species is abundant in the entire upper Mazaruni River basin, and especially in tributaries with rocky substrates and rich in rapids. Captured in black water sites with fairly high transparency (0.55-1.0 $\mathrm{m}$ Secchi depth), none to relatively fast currents $(0-0.6 \mathrm{~m} / \mathrm{s})$, temperature $\left(21.7-24.5^{\circ} \mathrm{C}\right), \mathrm{pH}(4.4-$ $4.8)$, dissolved oxygen $(5.2-9.3 \mathrm{mg} / \mathrm{L})$ and very low conductivity $(<10 \mu \mathrm{S})$.

\section{Mazarunia pala, new species Figs. 2b, 3b, 6a, 11-13}

Mazarunia sp. 2 López-Fernández et al., 2010: 1072, 1075, 1077, 1079-1081 [relationships within Geophagini].

Holotype. UG/CSBD 1668 (ex-ROM 89675), 62.7 mm SL, Guyana, Cuyuni-Mazaruni (Region 7), upper Mazaruni River, backwater channel on right bank in front of Warwata village, near mouth of Kamarang River, 551'56.8074”N, 60³6’32.076”W, 24 Mar 2011, H. López-Fernández, D.C. Taphorn \& E. Liverpool.
Paratypes. Guyana, upper Mazaruni River, Cuyuni-Mazaruni (Region 7): ROM 89658, 4, 32.5-74.2 mm SL (all measured), Mazaruni River Warwata village, near mouth of Kamarang River (same locality as HLF11-32), 16 Mar 2011, 551'56.8074'N, 60³6’32.076”W, H. López-Fernández, D. C. Taphorn \& E. Liverpool \& S. Refvik. ROM 89675, 3, 37.1-64.2 mm SL (1, 47.7 $\mathrm{mm}$ SL), collected with holotype; ROM 89737, 4, 40.1-72.8 mm SL (all measured), Mazaruni River, channel on left bank, downstream from Kamarang, $1 \mathrm{~km}$ upstream from Membaru, 5 55'1.776”'N, 60³6’13.4994”W, 13 Mar 2011, H. López-Fernández, D.C. Taphorn, E. Liverpool, S. Refvik \& K. Kramer. ROM 83753, 7, 39.5-48.2 mm SL (6, 39.5-44.1), Mazaruni River, sandy beach and associated embayment both created by gold-mining dredging, 541'35.412”N, 60²8'11.784"W, 18 Apr 2008, H. LópezFernández, D.C. Taphorn, E. Liverpool, \& C. Thierens. ROM 83870, 4, 20.4-56.8 mm SL (3, 38.0-56.8), Mazaruni River, beach on Mazaruni River downstream from Kamarang, 556'10.1034'N, 60³6'53.7834”W, 24 Apr 2008, H. López-Fernández, D.C. Taphorn, E. Liverpool, \& C. Thierens. ANSP 192032 (Ex. ROM 89737), 1, $53.2 \mathrm{~mm}$ SL, Mazaruni River, channel on left bank, downstream from Kamarang, $1 \mathrm{~km}$ upstream from Membaru, 555'1.776”N, 60³6'13.4994”W, 13 Mar 2011, H. LópezFernández, D. C. Taphorn, E. Liverpool, S. Refvik \& K. Kramer.

Diagnosis. Mazarunia pala can be distinguished from all other cichlids by the generic diagnostic characters. Phylogenetic analysis revealed that $M$. pala can be distinguished from its congeners by the derived absence of a parhypurapophysis (132-1), and externally, it is diagnosable by the presence of a dorsal-fin scaly pad with ctenoid scales (vs. no scaly pad in M. charadrica and M. mazarunii), a small suborbital stripe that is limited to the preopercle, by the absence of clearly discernible lateral bars on the body, and by its general pinkish coloration with a midlateral spot as the only melanic marking.

Description. Measurements are summarized in Table 1. No obvious sexual dimorphism. Head slightly broader ventrally. Dorsal head profile ascending from snout to vertical through posterior margin of orbit, angle more pronounced as body size increases, gently convex between tip of snout and orbit, where slightly concave, or profile gently concave in largest specimens (52.2 and $73.4 \mathrm{~mm} \mathrm{SL}$ ); ascending to dorsal-fin origin, but less steeply; dorsal base convex, ascending to about $7^{\text {th }}$ spine, then gently descending to last dorsal ray; dorsal profile of caudal peduncle straight to slightly concave to caudal-fin base. Ventral head profile straight or very slightly convex, descending to pelvic-fin insertion, flat to anus, then ascending through anal-fin base, most steeply through last 3-4 anal-fin rays to anal insertion; caudal peduncle gently ascending, slightly concave to caudal-fin base. Upper lip about half as wide as lower; lower lip widest in anterior half, covering distal portion of upper lip when mouth closed. Lower lip fold broad, discontinuous at dentary symphysis. Maxilla reaching from one fifth to one third of distance between nostril and orbit. Opercle, preopercle, cleithrum, supracleithrum and posttemporal smooth.

E1 24(3), 25(15)*, 26(1); scales between upper lateral line 
and dorsal fin 3(2), 31/2(17)* anteriorly and 1(1), 11/2(10)*, 2(5), $2^{1 / 2(3)}$ posteriorly. Scales on upper lateral line 15(1), 16(8), 17(9)*, 18(1), and lower lateral line 6(1), 7(7), 8(9)*, 9(2). Circumpeduncular scale rows 7 above, 7 below lower lateral line, ctenoid. Two scale rows between lateral lines. Opercle fully scaled, ctenoid, subopercle and cheek fully scaled, cycloid; interopercle caudally scaled, cycloid. Occipital and flank scales ctenoid. One column of postorbital scales, ctenoid. Lateral chest scales ctenoid, smaller than flank scales. Dorsal fin naked with narrow, ctenoid scaly pad along base of soft portion; anal, pectoral and pelvic fin naked; caudal fin with single row of ctenoid scales between rays, covering one fifth to one quarter of fin length. Accessory caudal-fin extensions of lateral line restricted to one tubed scale at base of dorsalfin between D3 and D4 and ventrally between V4 and V5.

Dorsal fin rays XV,7(2), XVI,7(3), XVI,8(5)*, XVII,7(7), XVII, 8(2); anal III,7(10), III,(9)*. Dorsal spines increasing in length from first to $8^{\text {th }}$, then approximately equal or slightly increasing to last, which is longest; membranous lappets behind all spines. Soft portion of dorsal fin pointed, $4^{\text {th }}$ ray longest, often slightly produced in larger $(>50.0 \mathrm{~mm} \mathrm{SL})$, reaching no more than half of caudal-fin length. Caudal fin symmetrical, distal margin slightly rounded. Anal fin pointed, $4^{\text {th }}$ ray slightly produced in large specimens $(>60.0 \mathrm{~mm} \mathrm{SL})$, reaching about quarter of caudal-fin length. Pectoral fin asymmetrical, rounded dorsally and caudally, $4^{\text {th }}$ ray longest; tips of longest rays barely reaching anus but not pelvic-fin rays or anal-fin origin. Pelvic spine about half length of first ray, which is longest and produced into filament reaching first or second anal-fin spine, each subsequent pelvic-fin ray shorter till last, which is about one third length of longest.

Outer premaxillary hemiseries with 7 to 13 thin, sharp, slightly recurved, unicuspid teeth, progressively smaller distally from symphysis. Four irregular rows of smaller, unicuspid teeth, separated from outermost row by wide gap. Dentary hemiseries with 15 to 20 teeth in outer row diminishing in size caudally, 2 to 3 inner rows with smaller teeth separated from outermost row by gap which progressively diminishes caudally, teeth in inner rows eventually join outer line. Dentary hemiseries separated by small symphyseal gap, particularly in two outermost rows.

External rakers on first gill arch 9(1), 10(3), 11(10), 12(5)*. Lower pharyngeal tooth plate (Fig. 6c) wider than long, length of bone $86 \%$ of width; dentigerous area $74 \%$ of width, $67 \%$ of length; $14-15$ teeth in posterior row; 8 in median row. Teeth thin, flattened laterally, unicuspid anteriorly and bicuspid postero-medially; cusps arranged antero-caudally with main cusp at tip of tooth and smaller anterior and lower to main; cusps straight to slightly recurved; anterior teeth more cylindrical than posterior. Two tooth plates on fourth ceratobranchial. Vertebrae $12+14=26(6)$.

Color in alcohol. Figs. 11-12. Base color light pinkish-brown; snout, region between posterior margin of maxilla to eye and top of head near supraoccipital darker brown or gray, black just posterodorsal to orbit, forming "cap" on top of head, markedly delimited ventrally from dusky beige preopercle, chin and throat, opercle beige ventrally, darker brown dorsally ventral margin of preopercle darker than rest of bone. Groove from posterior nares to anterior margin of eye light beige. Lips whitish. Infraorbital stripe absent. Branchiostegal membrane brown, contrasting with light chest. Body countershaded, darkest at dorsal midline, most scales with lighter centers, outlined with brown, body lightest on chest below pectoral fin. Light centers of scales align forming alternating rows of light spots, and thin, darker horizontal stripes, most notable on caudal peduncle. Flanks without welldefined vertical bars in adult or juveniles. Scaled third of caudal-fin base dark brown with white spots on scale centers. Caudal peduncle with very diffuse gray blotch, traces of third and fourth vertical bars of other species expressed as just faint blotches centered on E1 scale row. Midlateral blotch under tips of dorsal pectoral-fin rays; about five scales wide and three high, continuous with dark brown pigment along lateral midline, continuing anteriorly onto opercle. Slight trace of vertical bar from dorso-posterior margin of opercle to dorsal midline, united ventrally with brown pigment of opercle. Spinous portion of dorsal fin and proximal part of membranous portion maroon to brown, rest of fin dusky gray, rays of soft dorsal lighter than membranes distally, no light or dark spots. Caudal fin gray, rays lighter than membranes, darkest distally. Anal fin maroon to brown with darker pigment along rays. Pelvic fin dusky white, first rays black. Pectoral fin hyaline.

Color in life. From live specimens and photographs of recently captured specimens (Fig. 13). Background color brown to pinkish-tan. Some scales with lighter centers, especially on posterior fourth of body, forming horizontal rows of light spots ending on caudal peduncle. Scales of side with darker margins, forming reticulate pattern. Head from tip of snout to around eye and posterior to tip of supraoccipital maroon, dark brown or gray, anteriorly tapering light stripe from anterodorsal margin of eye to nare; light patch on dorsal edge of orbit, extending one or two scales dorsally. Upper lip brown anteriorly, white laterally, lower lip whitish. Iris emerald green with golden highlights where light stripe between nare and anterior edge of orbit meets iris; dark brown of head extending under eye turning purplish on upper body behind eye and on upper portion of opercle. Distinctly golden patches behind eye and at anterior end of upper lateral line; shiny silver to golden stripe extends postero-dorsally from below orbit across upper cheek, onto upper gill cover and onto body in humeral region, where it meets lowermost of two patches of light pink scales at anterior-most upper lateral line pores. Head below eye purplish pink or maroon, opercle gray with shiny golden highlights. Body anterior to pectoral fin pink, branchiostegal membrane yellow to orange. Ventral portion of head and ventrum between pectoral-fin bases light gray with pink overtones; abdomen whitish, scales outlined with thin gray margins. Supraorbital bar extends posterodorsad from eye but not well distinguished from general color of top of head. Lateral bars not well defined, or irregular, mottled 


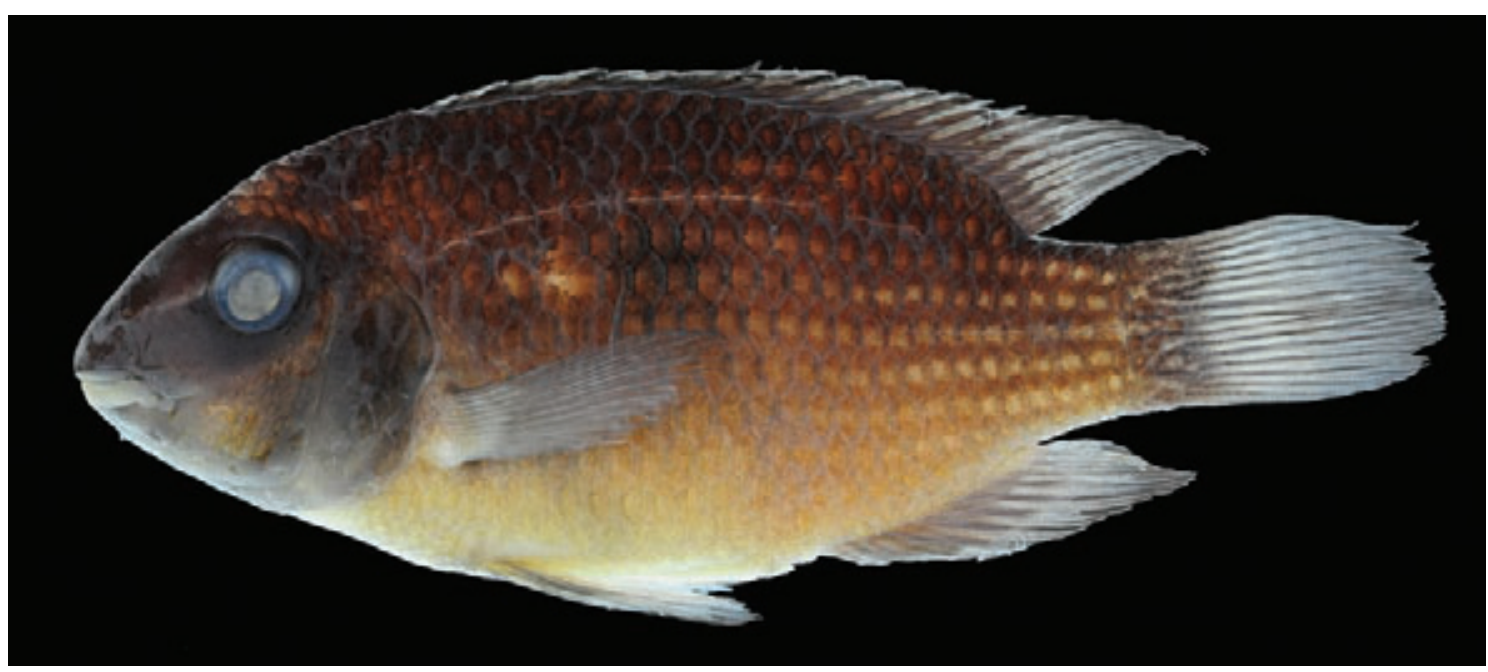

Fig. 11. Mazarunia pala, holotype, UG/CSBD 1668, 65.2 mm SL, Guyana, Cuyuni-Mazaruni (Region 7), Mazaruni River, backwater channel on right bank in front of Warwata village, near mouth of Kamarang River.

pattern of brownish-maroon and pink dorsally from E1, more or less uniformly pinkish grey below E0. Midlateral spot of darker black pigment between $8^{\text {th }}$ and $10^{\text {th }}$ dorsal spines, about 3 scales wide and 2 scales deep, entirely under upper lateral line, or barely overlapping it. Dorsal fin mostly maroon or reddish brown, first spine and distal tips of spines and membrane lappets dark gray for all of spinous portion, soft portion with maroon widely outlining rays, but transparent on distal $1 / 3$ of soft rays. Dorsal-fin spines darker than membranes. Pectoral fin transparent, rays thinly outlined with black. Pelvic whitish or light pink, spine and anterior rays outlined in black. Anal fin maroon to pink along base then translucent or dark gray distally, latter probably reproductive adults. Caudal fin dusky gray proximally, black pigment extending along rays for about $1 / 3$ of their lengths, membranes lightly dusky to greyish pink.

Geographic distribution. Mazarunia pala is known from four collection sites alongshore of the main channel of the upper Mazaruni River between the mouths of the Kukui and Kamarang rivers (Fig. 7).

Etymology. From the Greek pala $(\pi \alpha \lambda \alpha)$, meaning gold nugget, in reference to the golden spots behind and under the orbit. Also in reference to the fact that this species has only been collected in the main channel of the upper Mazaruni River, where a growing gold mining industry may be contributing to degradation of its habitat. To be regarded as an adjective in feminine form.

Habitat. Collected in very similar habitats to those of Mazarunia mazarunii, with which it seems to coexist, but apparently it is not as abundant as that species. Collected mostly in or near the main upper Mazaruni River channel in localities with sandy or slightly muddy substrates with structure formed by submerged or emerging grass and other riparian vegetation and some drift wood. Like the other species in the genus, $M$. pala appears to move at night into shallow, flooded banks with terrestrial vegetation. Temperature ranged from $21.7-24.5^{\circ} \mathrm{C}$, dissolved oxygen levels 5.2-9.3 mg/l, pH 4.4 and vey low conductivity $(<10 \mu \mathrm{S})$.

\section{Discussion}

With the description of two new species of Mazarunia, we have increased the number of species in the genus to three. More importantly, however, we continue to add to the astonishing number of endemic species found only in the upper reaches of the Mazaruni River basin. The three species of Mazarunia are, in some respects, uncommon among Neotropical cichlids. There is a large amount of morphological variation among the three species, visible in both external characters such as coloration (e.g. Figs. 4-5, 9-10, 12-13), and in osteological attributes such as the lower pharyngeal jaws (Fig. 6). This is a relatively uncommon phenomenon among Neotropical cichlids, which tend to show reduced intrageneric variation in morphology (López-Fernández et al., 2012). For example, Guianacara, although the sister group to Mazarunia, has a rather stereotyped morphology that makes differences between species very subtle (e.g. López-Fernández et al., 2006; Arbour \& López-Fernández, 2011). Differences in the lower pharyngeal jaw are particularly interesting, because they may suggest differences in trophic ecology as well. Mazarunia charadrica (Fig. 6a) has a relatively stout lower pharyngeal jaw with thick, wide medial teeth that suggests the species might be able to consume relatively hard types of prey. Conversely, Mazarunia pala has very thin teeth probably poorly suited for handling anything but soft types of prey and M. mazarunii has teeth somewhere between the other two species. Our field observations also suggest that habitat requirements may not be uniform across species of Mazarunia. Although relatively fast currents can be found nearly anywhere in the upper Mazaruni River basin, only $M$. charadrica seems widespread in the basin and it is the only 
species we have collected in true rapids, alongside other truly reophilic taxa (e.g. Characidium spp., Paulasquama callis, Neblinichthys spp.). Mazarunia mazarunii and M. pala appear to prefer more lentic conditions, and we have only been able to collect them in or near the main channel of the
Mazaruni, usually in backwaters or otherwise slow-current environments. While studies are under way (Liverpool et al. unpubl.), we essentially remain ignorant of the ecology of the fishes of the upper Mazaruni.

This situation is of great concern because our emerging

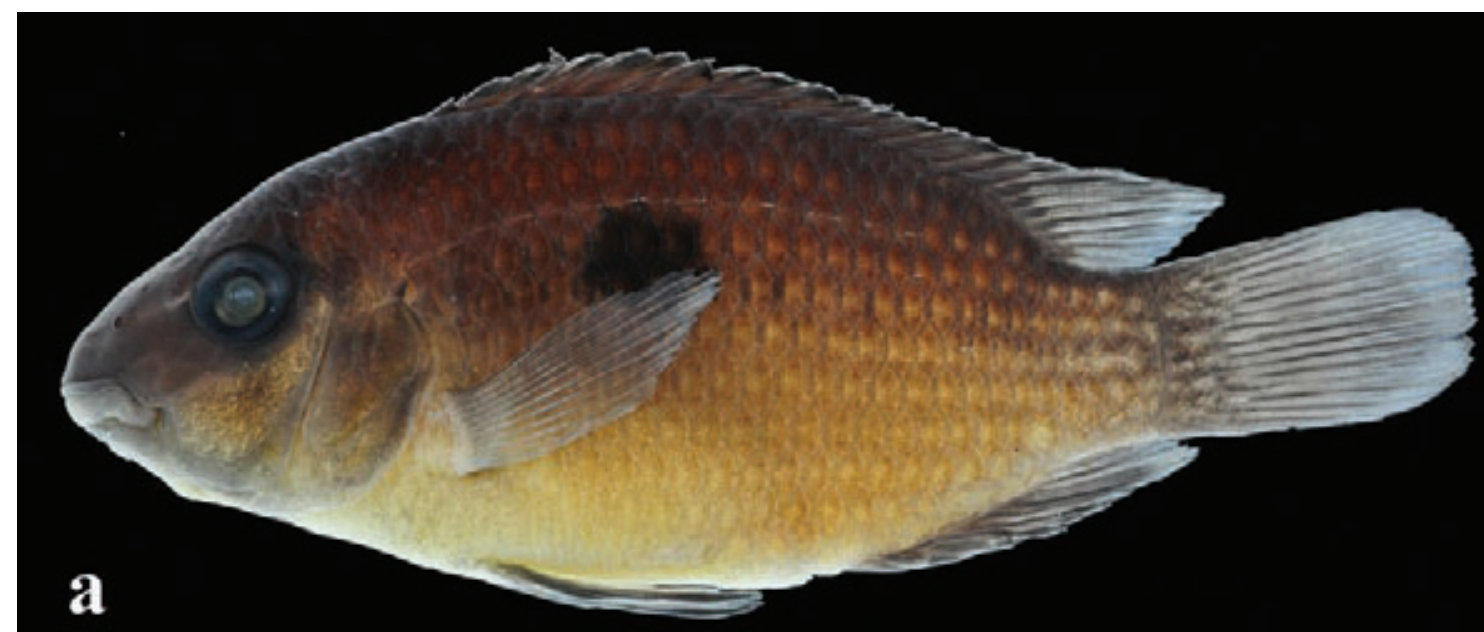

b
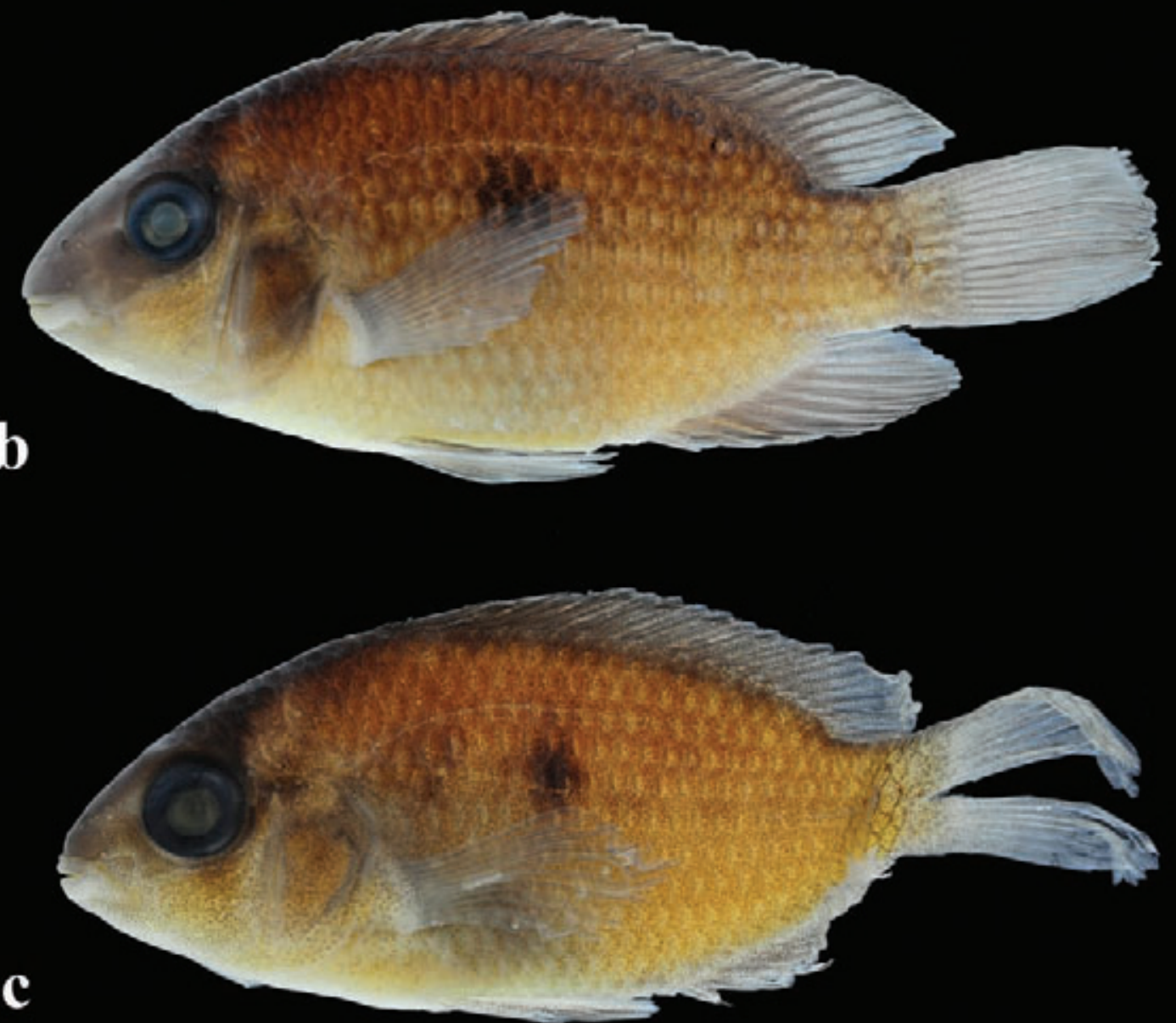

Fig. 12. Ontogenetic changes in body shape and coloration in Mazarunia pala. a) Paratype, $52.2 \mathrm{~mm}$ SL, ROM 89737, b) 39.9 mm SL, ROM 89737, c) 21.0 mm SL, ROM 83870. 


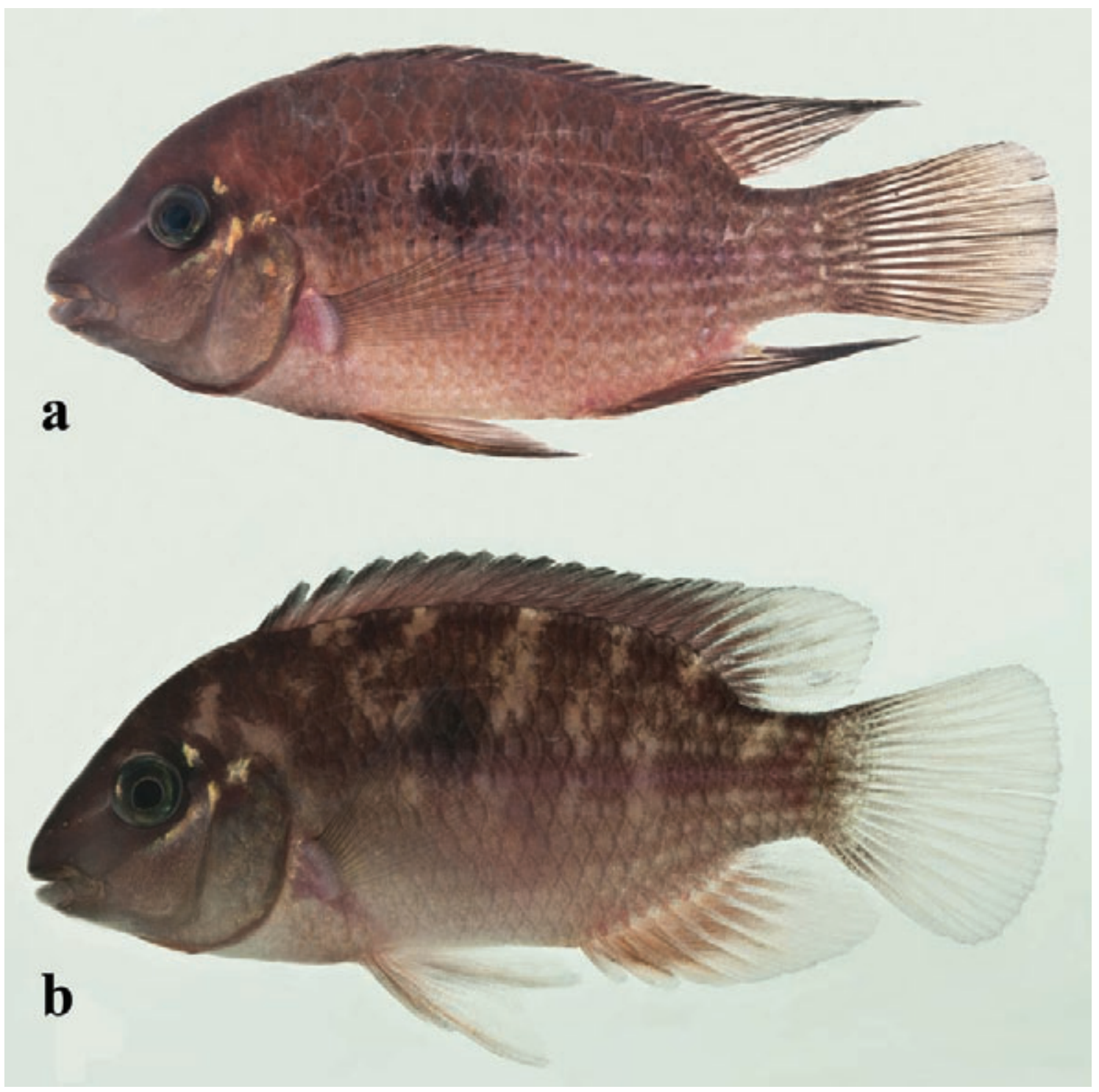

Fig. 13. Live colors of Mazarunia pala through ontogeny. a) adult individual, probably male, $76.7 \mathrm{~mm}$ SL, ROM 89531, shortly after capture, b) juvenile $50.0 \mathrm{~mm}$ SL, ROM 89675, shortly after capture.

understanding of Mazaruni fish taxonomy increasingly pictures a region with a large degree of endemism in a geographic area that is comparatively very small. Although still incomplete, our current inventory of the upper Mazaruni includes three described endemic genera: Mazarunia (Kullander, 1990), Derrhamia (Géry \& Zarske, 2002), and Paulasquama (Armbruster \& Taphorn, 2011). A fourth genus, Skiotocharax (Presswell et al., 2000), although supposedly present in the Berbice River basin as well, is probably also endemic to the upper Mazaruni. Three endemic species in genera with wider distributions have also been described: Apareiodon agmatos (Taphorn et al., 2008), and two species in the loricariid genus Neblinichthys (Taphorn et al., 2010). At least two other endemic genera in the families Crenuchidae and Hypopomidae are in process of being described, as are several endemic species in non-endemic genera. Beyond pure taxonomic diversity, these endemic taxa are also beginning to reveal a complex history of relationships within their respective families. Mazarunia has been found to be sister to Guianacara in a clade that has a geographic distribution restricted to the Guiana Shield and its surroundings, and whose relationships to other lowland cichlids are not overwhelmingly supported (López-Fernández et al., 2010). Both Paulasquama and Neblinichthys are part of a unique clade of ancistrin loricariids with extraordinary diversity in the Guiana Shield, and of potentially great relevance to understand the biogeography of other loricariid lineages in the Guiana Shield and the Orinoco basin (Armbruster \& Taphorn, 2008) and even some Andean basins (Lujan \& Armbruster, 2011). The parodontid Apareiodon agmatos is very distinct from other congeners and may represent an entirely different lineage within the family (Taphorn et al., 2008). In combination, 
however, our still fragmentary knowledge of these taxa strongly indicates that the upper Mazaruni River houses a large proportion of endemic freshwater fishes and as such it is a region of extreme importance both from a biological and a conservation point of view.

In this light, our observations during two 2011 expeditions to the region are increasingly worrying. While it appears that tributaries such as the Kako and Kukui Rivers are in near pristine state, the main channel of the upper Mazaruni River is being rapidly affected by gold mining activities. Mining-related sediment input has increased turbidity in the main channel as indicated by much lower Secchi depth readings. Siltation of shallow areas in the main channel is also evident in the high number of "tailings" beaches along the banks. This is in stark contrast with non-mined tributaries which are typically of deep, tea-colored water with nearly no suspended solids and high transparency. This is particularly concerning as work in other regions of the Guiana shield has demonstrated the negative impacts of even small-scale gold mining on fish community structure (e.g. Brosse et al., 2011). The upper Mazaruni basin is contained within a comparatively small geographic range, it harbors an extraordinary number of endemic freshwater fish species, and is under a rapidly increasing threat of direct habitat alteration due to mining activities in the region. While it is too early to say whether mining-related changes in the channel are having or will have significant effects on fish diversity and ecology, the combination of these three factors could conspire to diminish fish diversity in the region. The upper Mazaruni basin can thus be described as a vulnerable region of Guyana with a disproportionate potential for loss of biodiversity given its relatively small geographic area and large proportion of endemic taxa.

\section{Acknowledgements}

We are thankful to Kelly and Mary Kramer and their family in Kamarang who shared their home and experience while exploring the upper Mazaruni River and its tributaries during expeditions in 2008 and 2011. We are indebted to the captains and the people of the villages of Kamarang, Kako, Jawalla, Abbou, and Phillipai who graciously allowed us to explore the waters of their homelands. For their help in the field we thank Shannon Refvik, June Enright, George and Melford George, and Clydon Thierens. Calvin Bernard has provided us with invaluable logistic and personal support for our studies in Guyana and access to the equipment and facilities of the UG/CSBD at the University of Guyana in Georgetown. We also thank Prya Maharaj for helping with export permits and in the fish collection at UG. We are grateful to Sven Kullander for reading an earlier version of the manuscript and providing valuable comments to improve it. Rick Winterbottom did the photography for Figures 2 and 3 possible, and Jessica Arbour and Antonia Guidotti helped preparing Figure 6. For their help accessing collections under their care, we thank Mark Sabaj-Perez and John Lundberg (ANSP) and Erling Holm, Don Stacey, Mary Burridge and Marg Zur (ROM). Funding for field and laboratory components of this research was provided by U.S. National Science Foundation grant DEB 0516831 to K. Winemiller, R. Honeycutt and HLF, a Discovery Grant from the National Science and Engineering Research Council of Canada to HLF, ROM startup funds, and especially a Conservation Grant to HLF from the Schad Foundation Research Fund at the ROM to study and promote the conservation of the endemic fish fauna of the upper Mazaruni River basin. This is publication number 5 from an ongoing collaborative project between the Royal Ontario Museum and the Center for the Study of Biodiversity, University of Guyana to describe the freshwater fish diversity of Guyana.

\section{Literature Cited}

Arbour, J. H. \& H. López-Fernández. 2011. Guianacara dacrya, a new species from the Rio Branco and Essequibo River drainages of the Guiana Shield (Perciformes: Cichlidae). Neotropical Ichthyology, 9: 87-96.

Armbruster, J. W. \& D. C. Taphorn. 2008. A new species of Pseudancistrus from the Río Caroní, Venezuela (Siluriformes : Loricariidae). Zootaxa, 1731:33-41.

Armbruster, J. W. \& D. C. Taphorn. 2011. A new genus and species of weakly armored catfish from the upper Mazaruni River, Guyana (Siluriformes: Loricariidae). Copeia, 2011: 46-52.

Bremer, K. 1994. Branch support and tree stability. Cladistics, 10: 295-304.

Brosse, S. B. S., G. Grenouillet, M. Gevrey, K. Khazraie \& L. Tudesque. 2011. Small-scale gold mining erodes fish assemblage structure in small neotropical streams. Biodiversity and Conservation, 20: 1013-1026.

Géry, J. \& A. Zarske. 2002. Derhamia hoffmannorum, gen. et. sp. n. - a new pencil fish (Teleostei, Characiformes, Lebiasinidae), endemic from the Mazaruni River in Guyana. Zoologische Abhandlungen; Staatliches Museum für Tierkunde in Dresden, 52: 35-47.

Kullander, S. O. \& H. Nijssen. 1989. The cichlids of Surinam. Leiden, E. J. Brill, 256p.

Kullander, S. O. 1986. Cichlid fishes of the Amazon River drainage of Peru. Stockholm, Swedish Museum of Natural History, 431p.

Kullander, S. O. 1990. Mazarunia mazarunii (Teleostei: Cichlidae), a new genus and species from Guyana, South America. Ichthyological Exploration of Freshwaters, 1: 3-14.

Kullander, S. O. 1996. Heroina isonycterina, a new genus and species of cichlid fish from Western Amazonia, with comments on cichlasomine systematics. Ichthyological Exploration of Freshwaters, 7: 149-172.

Kullander, S. O. 1998. A phylogeny and classification of the Neotropical Cichlidae (Teleostei: Perciformes). Pp. 461-498. In: Malabarba, L. R., R. E. Reis, R. P. Vari, Z. M. S. Lucena \& C. A. S. Lucena (Eds.). Phylogeny and Classification of Neotropical Fishes. Porto Alegre, Edipucrs, 603p.

Kullander, S. O. 2003. Family Cichlidae (Cichlids). Pp. 605-654. In: Reis, R. E., S.O. Kullander \& C. J. Ferraris Jr. (Eds.). Check List of the Freshwater Fishes of South and Central America. Porto Alegre, Edipucrs, 729p.

López-Fernández, H., D. C. Taphorn \& S. O. Kullander. 2006. Two new species of Guianacara from the Guiana Shield of eastern Venezuela (Perciformes: Cichlidae). Copeia, 2006: 384-395.

López-Fernández, H., K. O. Winemiller, C. G. Montaña \& R. L. 
Honeycutt. 2012. Diet-M orphology Correlations in the Radiation of South A merican Geophagine Cichlids (Perciformes: Cichlidae: Cichlinae). PL OS ONE, 7: e33997, 14p.

López-Fernández, H., K. W inemiller \& R. L. Honeycutt. 2010. Multilocus phylogeny and rapid radiations in N eotropical cichlid fishes (Perciformes: Cichlidae: Cichlinae). M olecular Phylogenetics and Evolution, 55: 1070-1086.

López-Fernández, H., R. L. Honeycutt, M. L. J. Stiassny \& K. 0. Winemiller. 2005. M orphology, molecules, and character congruence in the phylogeny of South A merican geophagine cichlids (Perciformes, L abroidei). Zoologica Scripta, 34: 627-651.

L ujan, N. K.\& J. W. A rmbruster. 2011. The Guiana Shield. Pp. 211224. In: A lbert, J . \& R. E. Reis (Eds.). Historical Biogeography of N eotropical Freshwater Fishes. B erkel ey, U niversity of California Press, 388p.

M addison, W. \& D. R. M addison. 2000. M acClade: A nalysis of phylogeny and character evolution. Sunderland, Sinauer A ssociates, Inc, 492p.

Presswell, B., S. Weitzman \& T. B ergquist. 2000. Skiotocharax meizon, a new genus and species of fish from $G$ uyana with discussion of its relationships (Characiformes: Crenuchidae). Ichthyological Exploration of Freshwaters, 11: 175-192.

Sw offord, D. L. 2002. PA U P* Phylogenetic analysis using parsimony and other methods. Sunderland, Sinauer A ssociates, Inc. Version 4.0b10.

Taphorn, D. C., J. W. A rmbruster, H. López-Fernández \& C. R. Bernard. 2010. Description of N eblinichthys brevibracchium and $N$. echinasus from the upper M azaruni River, Guyana (Siluriformes: L oricariidae), and recognition of N. roraima and $\mathrm{N}$. yaravi as distinct species. Neotropical Ichthyology, 8: 615-624.

Taphorn, D., H. López-Fernández \& C. Bernard. 2008. A pareiodon agmatos, a new species from the upper $M$ azaruni River, Guyana (Tel eostei: Characiformes: Parodontidae). Zootaxa, 1925: 31-38.

Taylor, W. \& G. van Dyke. 1985. R evised procedures for staining and clearing small fishes and other vertebrates for bone and cartilage study. Cybium, 9: 107-119.

Submitted September 14, 2011 A ccepted July 15, 2012

Published September 28, 2012

Appendix 1 C oded morphological characters for phylogenetic analysis; character states for the remaining taxa in the analysis are given in López-Fernández et al. (2005).

\begin{tabular}{ccccccccccccccccccccccccccc} 
& 1 & 2 & 3 & 4 & 5 & 6 & 7 & 8 & 9 & 10 & 11 & 12 & 13 & 14 & 15 & 16 & 17 & 18 & 19 & 20 & 21 & 22 & 23 & 24 & 25 \\
\hline Mazaruni mazarunii & 0 & 1 & 0 & 1 & 1 & 1 & 0 & 0 & 0 & 1 & 0 & 1 & 1 & 0 & 0 & 0 & 0 & 0 & 0 & 1 & 1 & 0 & 0 & 2 & 1 \\
Mazarunia charadrica & 0 & 0 & 0 & 0 & 1 & 0 & 0 & 0 & 0 & 0 & 0 & 0 & 1 & 0 & 1 & 0 & 0 & 0 & 0 & 0 & 1 & 0 & 0 & 2 & 1 \\
Mazarunia pala & 0 & 1 & 0 & 0 & 1 & 0 & 0 & 0 & 0 & 1 & 0 & 1 & 1 & 0 & 0 & 0 & 0 & 0 & 0 & 0 & 1 & 0 & 0 & 2 & 1 \\
Guianacara dacrya & 0 & 1 & 0 & 1 & 0 & 0 & 0 & 0 & 0 & 1 & 0 & 1 & 1 & 0 & 0 & 0 & 0 & 0 & 0 & 0 & 0 & 0 & 0 & 2 & 1 \\
Guianacara owroewefi & 0 & 1 & 0 & 1 & 1 & 0 & 0 & 0 & 0 & 0 & 0 & 1 & 1 & 0 & 0 & 0 & 0 & 0 & 0 & 0 & 0 & 0 & 0 & 2 & 1 \\
\hline
\end{tabular}

\begin{tabular}{ccccccccccccccccccccccccccc} 
& 26 & 27 & 28 & 29 & 30 & 31 & 32 & 33 & 34 & 35 & 36 & 37 & 38 & 39 & 40 & 41 & 42 & 43 & 44 & 45 & 46 & 47 & 48 & 49 & 50 \\
\hline Mazaruni mazarunii & 0 & 0 & 0 & 0 & 1 & 1 & 1 & 0 & 1 & - & - & - & 1 & - & 1 & - & - & - & 1 & - & 0 & 0 & 0 & 0 & 1 \\
Mazarunia charadrica & 0 & 0 & 0 & 1 & 1 & 1 & 1 & 0 & 1 & - & - & - & 1 & - & 1 & - & - & - & 1 & - & 0 & 0 & 0 & 0 & 1 \\
Mazarunia pala & 0 & 0 & 0 & 0 & 1 & 1 & 1 & 0 & 1 & - & - & - & 0 & 0 & 1 & - & - & - & 1 & - & 0 & 0 & 0 & 0 & 1 \\
Guianacara dacrya & 0 & 0 & 0 & 0 & 1 & 1 & 1 & 0 & 1 & - & - & - & 1 & - & 1 & - & - & - & 1 & - & 0 & 0 & 0 & 0 & 1 \\
Guianacara owroewefi & 0 & 0 & 0 & 1 & 1 & 1 & 1 & 0 & 1 & - & - & - & 1 & - & 1 & - & - & - & 1 & - & 0 & 0 & 0 & 0 & 1 \\
\hline
\end{tabular}

\begin{tabular}{cccccccccccccccccccccccccc} 
& 51 & 52 & 53 & 54 & 55 & 56 & 57 & 58 & 59 & 60 & 61 & 62 & 63 & 64 & 65 & 66 & 67 & 68 & 69 & 70 & 71 & 72 & 73 & 74 & 75 \\
\hline Mazaruni mazarunii & 1 & 1 & 1 & 1 & 1 & 1 & 1 & 0 & 0 & 0 & 3 & 2 & 1 & 0 & 1 & - & - & 0 & 1 & 1 & 0 & 0 & 0 & 3 & 0 \\
Mazarunia charadrica & 0,1 & 0,1 & 0,1 & 0,1 & 1 & 1 & 1 & 0 & 0 & 0 & 3 & 2 & 1 & 0 & 1 & - & - & 0 & 0 & 0 & 0 & 0 & 1 & 3 & 0 \\
Mazarunia pala & 1 & 1 & 1 & 1 & 1 & 1 & 1 & 0 & 0 & 0 & 3 & 2 & 1 & 0 & 1 & - & - & 0 & 4 & 0 & 0 & 0 & 1 & 0 & 0 \\
Guianacara dacrya & 0 & 0 & 0 & 0 & 1 & 0 & 0,1 & 0 & 0 & 0 & 4 & 2 & 1 & 0 & 1 & - & - & 0 & 1 & 1 & 0 & 0 & 1 & 0 & 1 \\
Guianacara owroewefi & 0 & 0 & 0 & 0 & 1 & 0 & 0,1 & 0 & 0 & 0 & 4 & 1 & 1 & 0 & 1 & - & - & 0 & 1 & 1 & 0 & 0 & 1 & 0 & 1 \\
\hline
\end{tabular}

\begin{tabular}{cccccccccccccccccccccccccccc}
\hline & & & 76 & 78 & 79 & 80 & 81 & 82 & 83 & 84 & 85 & 86 & 87 & 88 & 89 & 90 & 91 & 92 & 93 & 94 & 95 & 96 & 97 & 98 & 99 & 100 \\
\hline Mazaruni mazarunii & 0 & 0 & 0 & 0 & 0 & 1 & 0 & 0 & 0 & 0 & 0 & 0 & 0 & 2 & 0 & 1 & 2 & 0 & 1 & 1 & 0 & 0 & 1 & 0 & 2 \\
Mazarunia charadrica & 0 & 0 & 0 & 0 & 0 & 1 & 0 & 0 & 0 & 0 & 0 & 0 & 0 & 1 & 0 & 0 & 2 & 0 & 1 & 1 & 0 & 0 & 1 & 0 & 1 \\
Mazarunia pala & 0 & 0 & 0 & 0 & 0 & 1 & 0 & 0 & 0 & 0 & 0 & 0 & 0 & 1 & 0 & 1 & 2 & 0 & 1 & 1 & 0 & 0 & 1 & 0 & 2 \\
Guianacara dacrya & 0 & 0 & 0 & 1 & 1 & 1 & 0 & 0 & 0 & 0 & 0 & 0 & 0 & 1 & 0 & 1 & 1 & 0 & 1 & 0 & 1 & 1 & 0 & 0 & 0 \\
Guianacara owroewefi & 0 & 0 & 0 & 1 & 1 & 1 & 0 & 0 & 0 & 1 & 0 & 0 & 0 & 1 & 0 & 1 & 1 & 0 & 1 & 0 & 0 & 0 & 0 & 0 & 0 \\
\hline
\end{tabular}

\begin{tabular}{lllllllllllllllllllllllll}
\hline 101 & 102 & 103 & 104 & 105 & 106 & 107 & 108 & 109 & 110 & 111 & 112 & 113 & 114 & 115 & 116 & 117 & 118 & 119 & 120 & 121 & 122 & 123 & 124 & 125 \\
\hline
\end{tabular}

\begin{tabular}{ccccccccccccccccccccccccccc}
\hline Mazaruni mazarunii & 4 & 0 & 2 & 0 & 1 & 1 & 0 & 0 & 1 & 0 & 0 & 0 & 2 & 0 & 0 & 3 & 1 & 0 & 1 & 1 & 1 & 0 & 0 & 2 & 0 \\
Mazarunia charadrica & 2 & 0 & 2 & 0 & 1 & 1 & 0 & 0 & 1 & $?$ & 0 & 0 & 2 & 0 & 0 & 3 & 1 & 0 & 1 & 1 & 1 & 2 & 0 & 2 & 1 \\
Mazarunia pala & 4 & 0 & 2 & 0 & 1 & 1 & 0 & 0 & 1 & $?$ & 0 & 0 & 2 & 0 & 0 & 3 & 1 & 0 & 1 & 1 & 1 & 2 & 0 & 2 & 1 \\
Guianacara dacrya & 0 & 0 & 0 & 0 & 1 & 1 & 0 & 0 & 1 & 0 & 0 & 0 & 2 & 2 & 2 & 1 & 1 & 0 & 1 & 1 & 1 & 1 & 0 & 2 & 1 \\
Guianacara owroewefi & 0 & 0 & 0 & 0 & 1 & 1 & 0 & 0 & 1 & 0 & 0 & 0 & 2 & 0 & 2 & 1 & 1 & 0 & 1 & 1 & 1 & 1 & 0 & 2 & 1 \\
\hline
\end{tabular}

\begin{tabular}{|c|c|c|c|c|c|c|c|c|c|c|c|}
\hline & 126 & 127 & 128 & 129 & 130 & 131 & 132 & 133 & 134 & 135 & 136 \\
\hline Mazaruni mazarunii & 1 & 1 & 0 & 1 & 0 & 0 & 0 & 0 & 0 & 1 & 0 \\
\hline M azarunia charadrica & 1 & 1 & 0 & 1 & 0 & 0 & 0 & 0 & 0 & 1 & 0 \\
\hline Mazarunia pala & 1 & 1 & 0 & 1 & 0 & 0 & 1 & 0 & 0 & 1 & 0 \\
\hline Guianacara dacrya & 1 & 0 & 0 & 1 & 0 & 0 & 0 & 0 & 0 & 1 & 0 \\
\hline Guianacara owroewefi & 1 & 0 & 0 & 1 & 0 & 0 & 0 & 0 & 0 & 1 & 0 \\
\hline
\end{tabular}


Appendix 2. Taxa and data used for phylogenetic analyses. For details of sequences and characters see $L$ ópez-F ernández et al., 2010, and López-Fernández et al. (2005), respectively.

\begin{tabular}{|c|c|c|}
\hline Taxon & M orphological data & M olecular data \\
\hline Acarichthys heckelii & $\mathrm{X}$ & $X$ \\
\hline Apistogramma agassizi & $\mathrm{X}$ & $X$ \\
\hline Apistogramma hoignei & $X$ & $x$ \\
\hline Apistogramma iniridae & - & $x$ \\
\hline Apistogramma pucallpaensis & $x$ & $x$ \\
\hline Astronotus sp. & $\mathrm{X}$ & $\mathrm{X}$ \\
\hline Biotodoma cupido & $x$ & $x$ \\
\hline Biotodoma wavrini & $x$ & $\mathrm{X}$ \\
\hline Biotoecus dicentrarchus & $\mathrm{X}$ & $\mathrm{X}$ \\
\hline Chaetobranchopsis orbicularis & - & $\mathrm{X}$ \\
\hline Chaetobranchus flavescens & - & $X$ \\
\hline Cichla intermedia & $\mathrm{X}$ & $x$ \\
\hline Cichla orinocensis & $\mathrm{X}$ & $\mathrm{X}$ \\
\hline Cichla temensis & $x$ & $x$ \\
\hline Cichlasoma orinocense & $x$ & $\mathrm{X}$ \\
\hline Crenicara punctulatum & $\mathrm{X}$ & $\mathrm{X}$ \\
\hline Crenicichla geayi & $x$ & $x$ \\
\hline Crenicichla lenticulata & - & $x$ \\
\hline Crenicichla lugubris & $\mathrm{X}$ & $\mathrm{X}$ \\
\hline Crenicichla lugubris G uyana & - & $\mathrm{X}$ \\
\hline Crenicichla multispinosa & - & $\mathrm{X}$ \\
\hline Crenicichla reticulate & - & $x$ \\
\hline Crenicichla sveni & $\mathrm{X}$ & $\mathrm{X}$ \\
\hline Crenicichla wallacii & $x$ & $x$ \\
\hline Dicrossus & $x$ & $\mathrm{X}$ \\
\hline Geophagus abalios & $x$ & $x$ \\
\hline Geophagus brasiliensis & $x$ & $X$ \\
\hline Geophagus sp. "Cuyuni" & $x$ & $x$ \\
\hline G eophagus dicrozoster & $x$ & $x$ \\
\hline Geophagus grammepareius & $x$ & $x$ \\
\hline Geophagus harreri & ? & $\mathrm{X}$ \\
\hline G eophagus steindachneri & $\mathrm{x}$ & $\mathrm{X}$ \\
\hline G eophagus surinamensis & $\mathrm{X}$ & $\mathrm{X}$ \\
\hline Geophagus taeniopareius & - & $X$ \\
\hline G eophagus sp. "Takutu" & - & $x$ \\
\hline Guianacara dacrya & $\mathrm{X}$ & $x$ \\
\hline Guianacara owroewefi & $\mathrm{X}$ & $X$ \\
\hline Guianacara stergiosi & $\mathrm{X}$ & $X$ \\
\hline Gymnogeophagus balzanii & $\mathrm{X}$ & $X$ \\
\hline Gymnogeophagus rhabdotus & $\mathrm{X}$ & $\mathrm{X}$ \\
\hline Gymnogeophagus setequedas & - & $\mathrm{X}$ \\
\hline Hoplarchus psittacus & $\mathrm{x}$ & $\mathrm{X}$ \\
\hline Mazarunia mazarunii & $\mathrm{X}$ & $x$ \\
\hline Mazarunia pala & $x$ & $x$ \\
\hline M azarunia charadrica & $\mathrm{x}$ & $\mathrm{X}$ \\
\hline M esonauta egregious & $\mathrm{X}$ & $x$ \\
\hline M ikrogeophagus altispinosa & $x$ & $x$ \\
\hline Mikrogeophagus ramirezi & $\mathrm{X}$ & $\mathrm{X}$ \\
\hline Retroculus sp. & $\mathrm{X}$ & $x$ \\
\hline Satanoperca daemon & $\mathrm{X}$ & $x$ \\
\hline Satanoperca jurupari & $x$ & $\mathrm{X}$ \\
\hline Satanoperca leucosticta & - & $\mathrm{X}$ \\
\hline Satanoperca mapiritensis & $\mathrm{X}$ & $\mathrm{X}$ \\
\hline Satanoperca pappaterra & $\mathrm{X}$ & $\mathrm{X}$ \\
\hline Taeniacara candidi & $x$ & $\mathrm{X}$ \\
\hline Teleocichla aff. proselytus & - & $\mathrm{X}$ \\
\hline
\end{tabular}

Appendix 3. U nique morphological synapomorphies in the strict consensus tree presented in Fig. 1. Character changes highlighted in bold indicate that a single derived state is shared by all taxa within a clade; characters in regular font indicate further state changes within a clade to a different derived condition. Character states labeled as "E" represent an equivocal character state reconstruction in the stem node for a clade. See text for details of phylogenetic analyses. See López-Fernández et al. (2005) for description of characters.

\begin{tabular}{|c|c|c|c|c|c|c|}
\hline Character & & & Branch & & Chan & \\
\hline 14 & Node63 & $\rightarrow$ & Satanoperca jurupari & $\mathbf{0}$ & $\rightarrow$ & 6 \\
\hline 14 & Node 68 & $\rightarrow$ & Cichla & 0 & $\rightarrow$ & 6,7 \\
\hline 17 & Node 106 & $\rightarrow$ & B iotoecus dicentrarchus & $\mathbf{0}$ & $\rightarrow$ & 1 \\
\hline 19 & Node 106 & $\rightarrow$ & B iotoecus dicentrarchus & $\mathbf{0}$ & $\rightarrow$ & 1 \\
\hline 22 & Node 68 & $\rightarrow$ & Retroculus & $\mathbf{0}$ & $\rightarrow$ & 1 \\
\hline 24 & Node 104 & $\rightarrow$ & Crenicichla sveni & $\mathbf{0}$ & $\rightarrow$ & 1 \\
\hline 32 & Node 104 & $\rightarrow$ & Crenicichla sveni & $\mathbf{0}$ & $\rightarrow$ & 2 \\
\hline 38 & Node 70 & $\rightarrow$ & Cichlasoma orinocense & $\mathbf{0}$ & $\rightarrow$ & 2 \\
\hline 38 & Node84 & $\rightarrow$ & 'G eophagus' steindachneri & $\mathbf{0}$ & $\rightarrow$ & 3 \\
\hline 41 & Node68 & $\rightarrow$ & Cichla & $\mathbf{0}$ & $\rightarrow$ & 1 \\
\hline 42 & Node68 & $\rightarrow$ & Cichla & $\mathbf{0}$ & $\rightarrow$ & 1 \\
\hline 44 & Node 70 & $\rightarrow$ & Cichlasoma orinocense & $\mathbf{0}$ & $\rightarrow$ & 2 \\
\hline 49 & Node 65 & $\rightarrow$ & Node 60 & 0 & $\rightarrow$ & 1 \\
\hline 57 & Node 106 & $\rightarrow$ & B iotoecus dicentrarchus & $\mathbf{0}$ & $\rightarrow$ & 6 \\
\hline 57 & Node 74 & $\rightarrow$ & B iotodoma cupido & $\mathbf{0}$ & $\rightarrow$ & 3 \\
\hline 58 & Node 68 & $\rightarrow$ & Retroculus & $\mathbf{0}$ & $\rightarrow$ & 1 \\
\hline 59 & Node 58 & $\rightarrow$ & A pistogramma pucallpaensis & $\mathbf{0}$ & $\rightarrow$ & 1 \\
\hline 61 & Node 68 & $\rightarrow$ & Cichla & $\mathrm{E}$ & $\rightarrow$ & 8,7 \\
\hline 61 & Node 60 & $\rightarrow$ & Apistogramma & $\mathrm{E}$ & $\rightarrow$ & 2 \\
\hline $\mathbf{6 3}$ & Node 69 & $\rightarrow$ & M esonauta egregius & 1 & $\rightarrow$ & 2 \\
\hline 70 & Node 70 & $\rightarrow$ & Crenicara punctulatum & $\mathbf{E}$ & $\rightarrow$ & 3 \\
\hline $\mathbf{7 2}$ & Node 70 & $\rightarrow$ & Dicrossus & $\mathbf{E}$ & $\rightarrow$ & 2 \\
\hline 76 & Node 107 & $\rightarrow$ & Node 106 & 0 & $\rightarrow$ & 1 \\
\hline 77 & Node 107 & $\rightarrow$ & Node 106 & 0 & $\rightarrow$ & 1 \\
\hline 78 & Node68 & $\rightarrow$ & Cichla & $\mathbf{0}$ & $\rightarrow$ & 1 \\
\hline 83 & Node 106 & $\rightarrow$ & Crenicichla & 0 & $\rightarrow$ & 1 \\
\hline 84 & Node60 & $\rightarrow$ & Taeniacara candidi & $\mathbf{0}$ & $\rightarrow$ & 2 \\
\hline 84 & Node68 & $\rightarrow$ & Cichla & $\mathbf{0}$ & $\rightarrow$ & 1 \\
\hline 89 & Node95 & $\rightarrow$ & Mazarunia mazarunii & $\mathbf{0}$ & $\rightarrow$ & 2 \\
\hline 90 & Node 106 & $\rightarrow$ & Crenicichla & $\mathrm{E}$ & $\rightarrow$ & 2 \\
\hline 92 & Node 106 & $\rightarrow$ & Crenicichla & $\mathrm{E}$ & $\rightarrow$ & 4 \\
\hline 92 & Node 65 & $\rightarrow$ & Node 60 & $\mathrm{E}$ & $\rightarrow$ & 3 \\
\hline 94 & Node 68 & $\rightarrow$ & Retroculus & $\mathbf{0}$ & $\rightarrow$ & 3 \\
\hline 94 & Node 87 & $\rightarrow$ & Node 84 & 1 & $\rightarrow$ & 2 \\
\hline 98 & Node 70 & $\rightarrow$ & Cichlasoma orinocense & $\mathbf{0}$ & $\rightarrow$ & 2 \\
\hline 99 & Node 65 & $\rightarrow$ & Satanoperca & 0 & $\rightarrow$ & 1 \\
\hline 100 & Node 96 & $\rightarrow$ & Mazarunia & 0 & $\rightarrow$ & 2,1 \\
\hline 101 & Node 96 & $\rightarrow$ & Mazarunia & 0 & $\rightarrow$ & 4,2 \\
\hline 101 & Node68 & $\rightarrow$ & Retroculus & $\mathbf{0}$ & $\rightarrow$ & 3 \\
\hline 102 & Node 68 & $\rightarrow$ & Cichla & $\mathbf{0}$ & $\rightarrow$ & 2 \\
\hline 104 & Node 107 & $\rightarrow$ & Node 106 & 0 & $\rightarrow$ & 1 \\
\hline 108 & Node 68 & $\rightarrow$ & Cichla & $\mathbf{0}$ & $\rightarrow$ & 1 \\
\hline 108 & Node 106 & $\rightarrow$ & Crenicichla & 0 & $\rightarrow$ & 2 \\
\hline 112 & Node68 & $\rightarrow$ & Cichla & $\mathbf{0}$ & $\rightarrow$ & 1 \\
\hline 116 & Node95 & $\rightarrow$ & Mazarunia & $\mathbf{0}$ & $\rightarrow$ & 3 \\
\hline 128 & Node 87 & $\rightarrow$ & Gymnogeophagus & 0 & $\rightarrow$ & 0 \\
\hline 129 & Node 65 & $\rightarrow$ & Node 60 & 1 & $\rightarrow$ & 2 \\
\hline 130 & Node 106 & $\rightarrow$ & Crenicichla & 0 & $\rightarrow$ & 1 \\
\hline 131 & Node99 & $\rightarrow$ & Crenicichla geayi & $\mathbf{0}$ & $\rightarrow$ & 4 \\
\hline 133 & Node 84 & $\rightarrow$ & Geophagus & 0 & $\rightarrow$ & 1 \\
\hline 136 & Node 70 & $\rightarrow$ & Node 69 & 0 & $\rightarrow$ & 1 \\
\hline
\end{tabular}

